\title{
Environment Protection in Fertilizer Plants
}

\author{
Prem Baboo \\ DGM (Production \& Process)
}

\begin{abstract}
Environmental protection is the practice of protecting the natural environment by individuals, organizations and governments. Wastewaters from chemical fertilizer industry mainly contain organics, alcohols, ammonia, nitrates, phosphorous, heavy metals such as cadmium and suspended solids. The nature of effluent streams varies in terms of its constituents and complexity. Thispaper intended to the standpoint of the production technology and environment management, harmful emissions typical nitrogen-based fertilizer plants producing ammonia and urea using the advanced available technologies in the Dangote fertilizer plant. The study centered on the development of a multi-treatment advanced biological system which comprises enzymatic hydrolysis and biological nitrification to produce effluent suitable for discharge to the Atlantic Ocean.A wide variety of method and on line analysers are installed for monitoring emission, advanced and high level of protection \& method adopted to reduce the emission and control the pollution. Dangote Group is one of the most diversified business conglomerates in Africa with a hard - earned reputation for excellent business practices and products' quality.HSE instructions and procedures have developed taking into account any relevant national and local regulations as well as applicable statutory requirements. It was observed that the effluent treatment strategy requires careful identification and application of suitable treatment method on the basis of the nature of the effluent.
\end{abstract}

Keyword:- Ammonia, Urea, Fertilizers, Environmental impact, pollution abatement, wastewater, treatment.DM plant, Bagging Plants. Biological treatment.

\section{INTRODUCTION}

In the design itself necessary systems is provided to have negligible impact on environment. An effluent treatment Plant has been designed to cater the treatment needs of effluent generated from various sections of the Unit. In addition, adequate provisions have been made in each Plant to ensure maximum recycle of process condensate with minimum generation of effluent. Dangote Fertilizer Project consists in the realization of an Ammonia and Urea complex with associated facilities. Ammonia and Urea complex includes:

2x2, 200 MTPD Ammonia Trains based on HTAS technology (and BASF technology for $\mathrm{CO}_{2}$ capture in Ammonia Plants).

$>2 \times 3,850$ MTPD Melt Urea Trains based on Saipem Technology.

$>$ 2x3, 850 MTPD Urea Granulation Trains based on Udhe Fertilizer technology. Associated Utility Units.

$>$ The total power requirement of the complex is produced by three Steam Turbine Generators The capacities of STGs cover the power requirement of Ammonia Unit, Urea Unit and Granulation Unit plus Utility facilities. Each Steam Turbine Generator produce approximately $41 \mathrm{MW}$ (rated point) at $11 \mathrm{KV}$ (island mode);

$>3300 \mathrm{M}^{3} / \mathrm{hr}$ raw water treatment plant received from Lekki Lagoon.

$>$ Waste water treatment plant including biological treatments and treated waste is send to Atlantic Ocean in deep area one KM inside the ocean.

$>$ Wet scrubbing of granulation plant air to recover urea and ammonia

\section{PROCESS DESCRIPTION AND SOURCE OF EFFLUENTS}

The main source of effluent is Ammonia Plant, Urea Plant, Granulation Plant, and Offsite in Acid \& alkali pollutant generation in DM plant.

Solid Pollutants-Urea dust, Urea, Catalyst, Catalyst dust, Sludge lagoon, Resin

\section{CONTNUOUS LIQUID EFFLUENTS}

Continuous liquid effluents sources from Urea Sections are the following:

Clean process condensate from waste water treatment section. This common section provides conditions to process the water containing $\mathrm{NH}_{3}, \mathrm{CO}_{2}$ and urea coming out of vacuum system, so as to have an almost $\mathrm{NH}_{3}, \mathrm{CO}_{2}$ urea free process condensate to be sent to utility units. In ammonia plant liquid effluents are MDEA solution. Steam condensate from common steam condensate recovery section.

\section{DISCONTNUOUSGASEOUS EFFLUENTS}

Urea Plant high pressure loop vent is connected to blow down system. Tanks vent header is connected to Blow down. Waste water tank vent is connected to Blow down. The process safety valves for unit's train one and granulation are connected respectively to blow down separator and for unit common section are connected to Blow down. The low pressure process vent, normally closed, are connected for train one and train respectively to discontinuous vent stacks. The waste water treatment section vent from waste water section normally closed is connected to vent stack.

In Ammonia Plant, the Process vents and the pressure safety valves (PSV) vents are delivered to the appropriate blow down header or relieved to a safe high point location taking into account the material being vented. Process vents and safety relief valves (PSV) that relieve steam and water are routed to the atmosphere. Primary reformer flue gas and $\mathrm{CO}_{2}$ vent from $\mathrm{CO}_{2}$ removal section are relieved to safe high point location. Hazardous releases from the ammonia plant are sent for disposal by flaring. Two flare systems are foreseen. 
1. A process gas flares system for disposal of gases from the front-end of the ammonia plant. The gases typically be natural gas and reformed process gas containing hydrocarbons, carbon oxides, and water vapours.

2. An ammonia flare system for disposal of fluids from the back-end of the ammonia plant. The gases aretypically synthesis gas containing ammonia and ammonia vapours.

Relief gases containing ammonia is not mixed with gases containing carbon dioxide due to the risk of carbamate/ammonium bicarbonate formation. All process vents and all PSVs involved in the front-end section and around Syngas Compressor make-up and circulation stages are connected to Process Flare system through front end main flare header 46 inch and front end secondary header 24 inch. In Urea Plant, urea solution sections normally have the following sources of pollution:

1. Ammonia from inert vents.

2. Ammonia and urea in liquid effluents.

Ammonia vented with inerts is minimized in Saipem plants since the quantity of air required for passivation, is much less than in other processes. Furthermore, water scrubbing is provided for all the vents to recover the ammonia in the inerts.

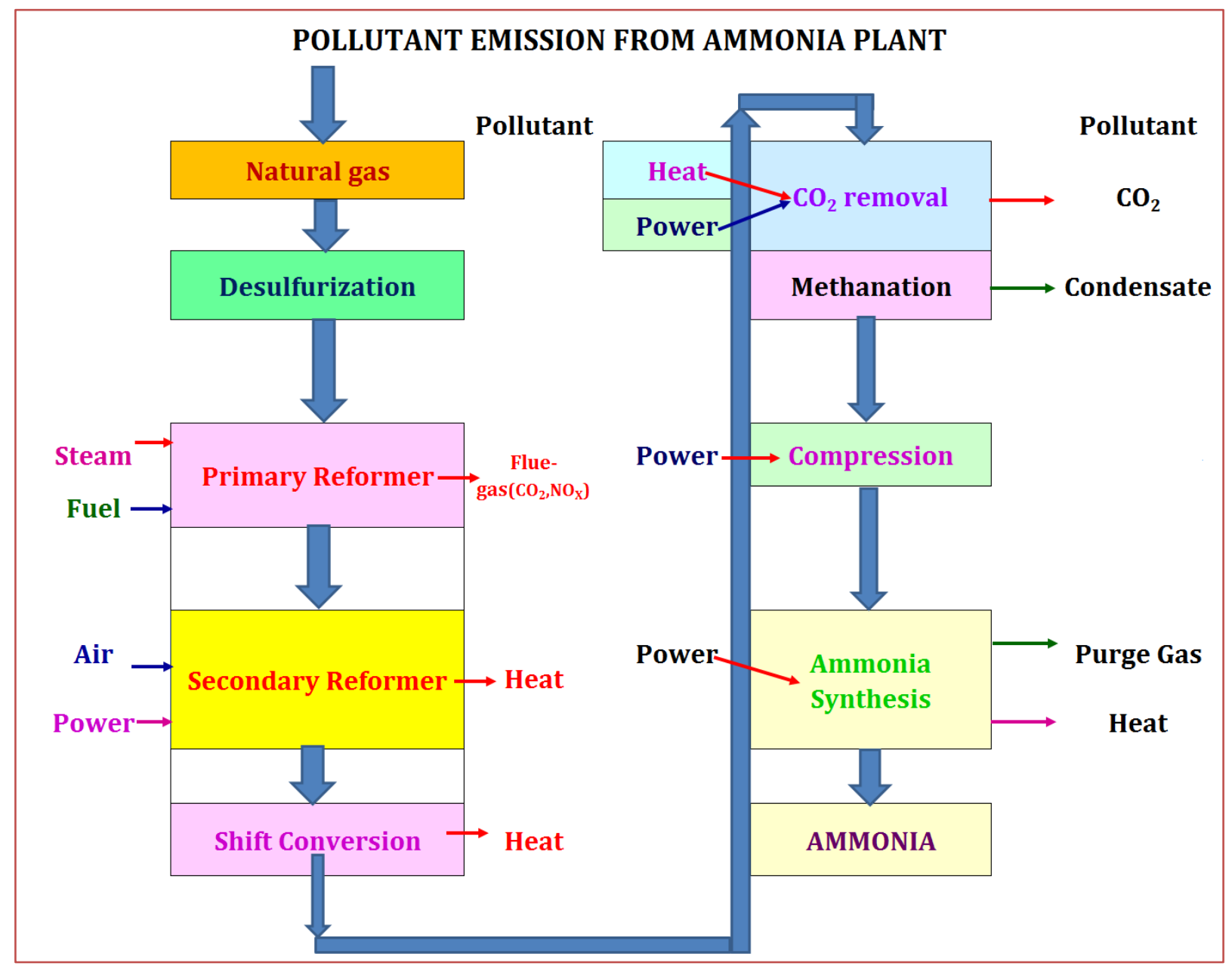

Fig-1(Ammonia plant Pollutants) 


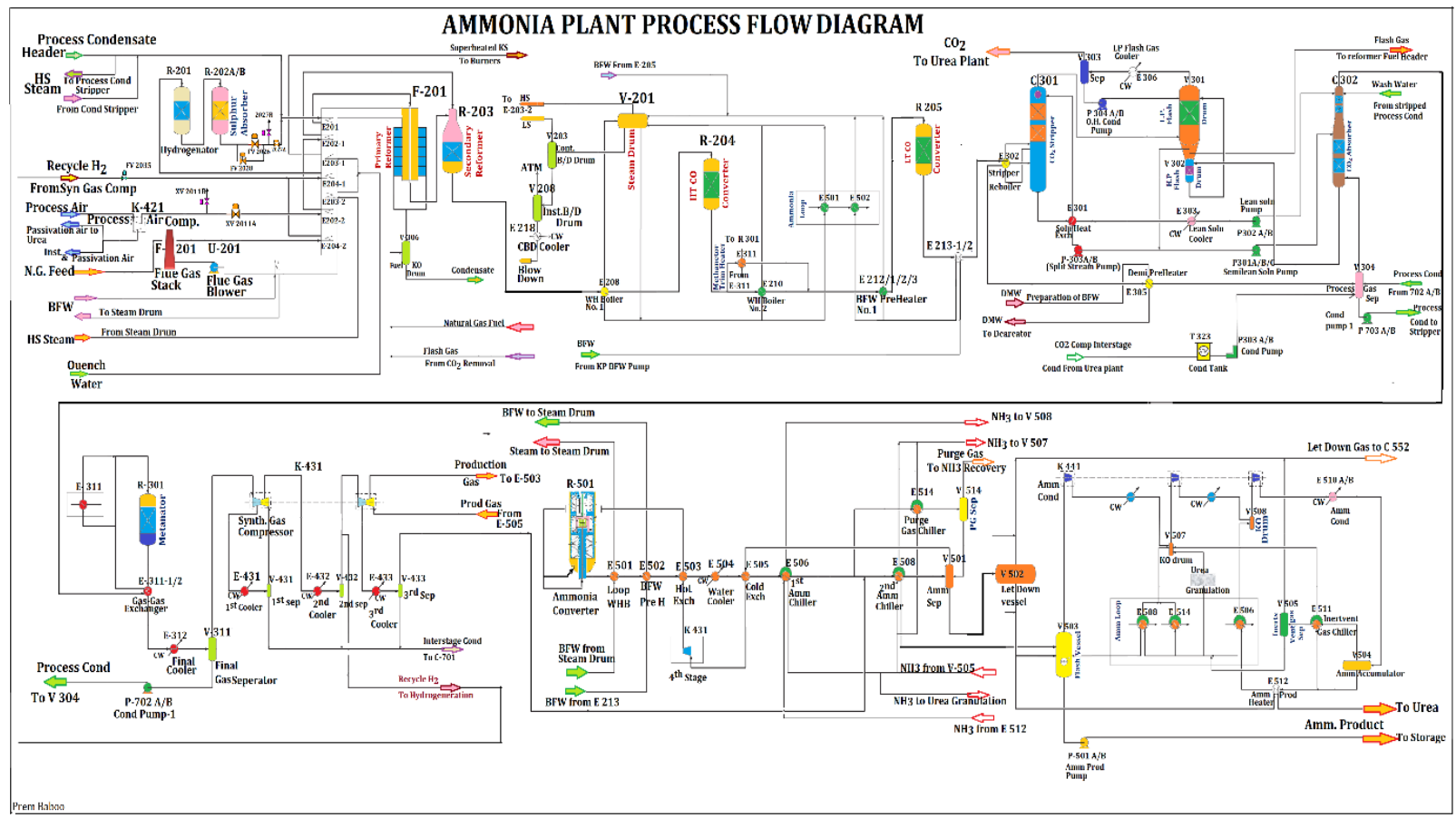

Fig-2(Ammonia Plant Flow diagram and emission)

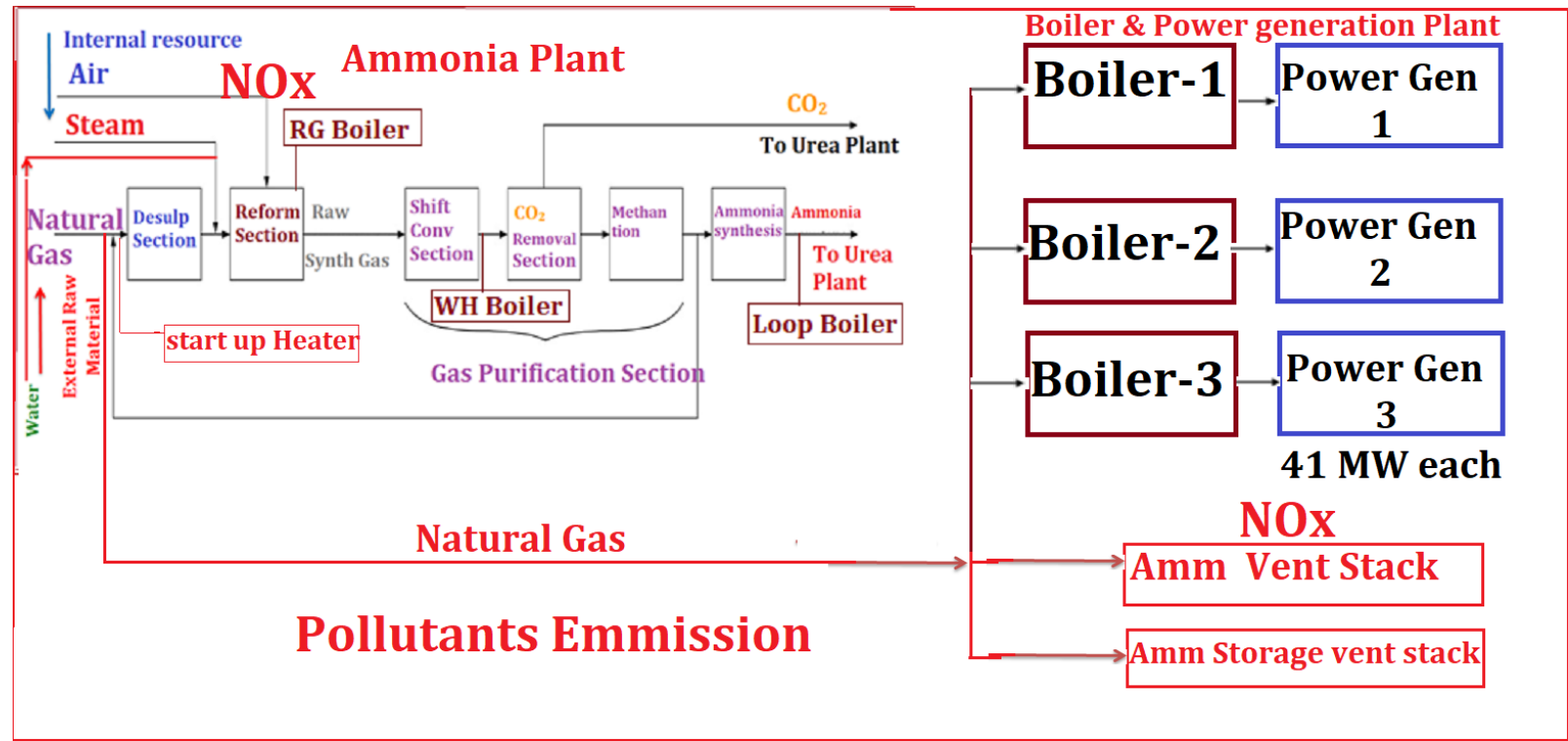

Fig-3(Natural Gas distribution) 


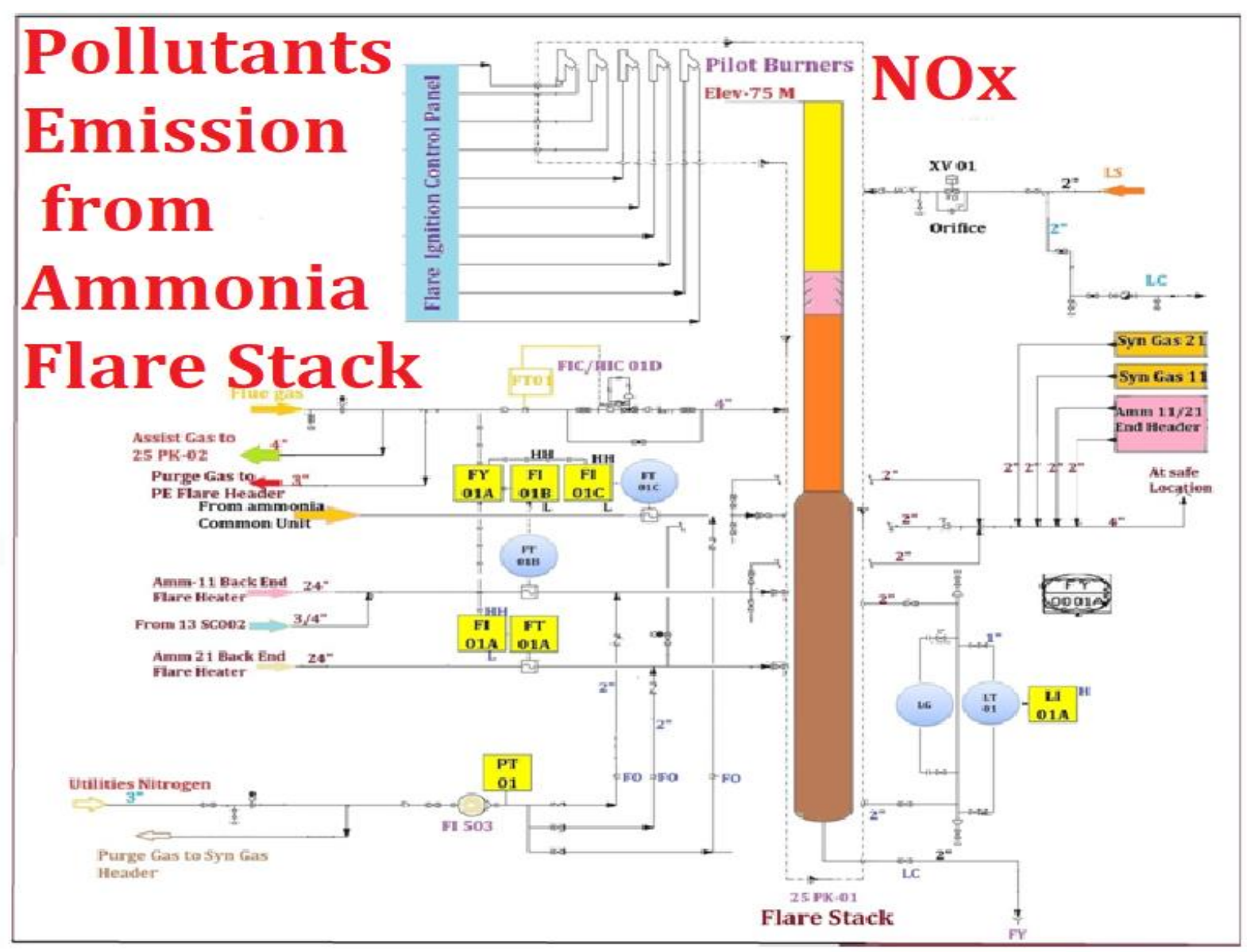

Fig-4(Emission from ammonia flare stack)

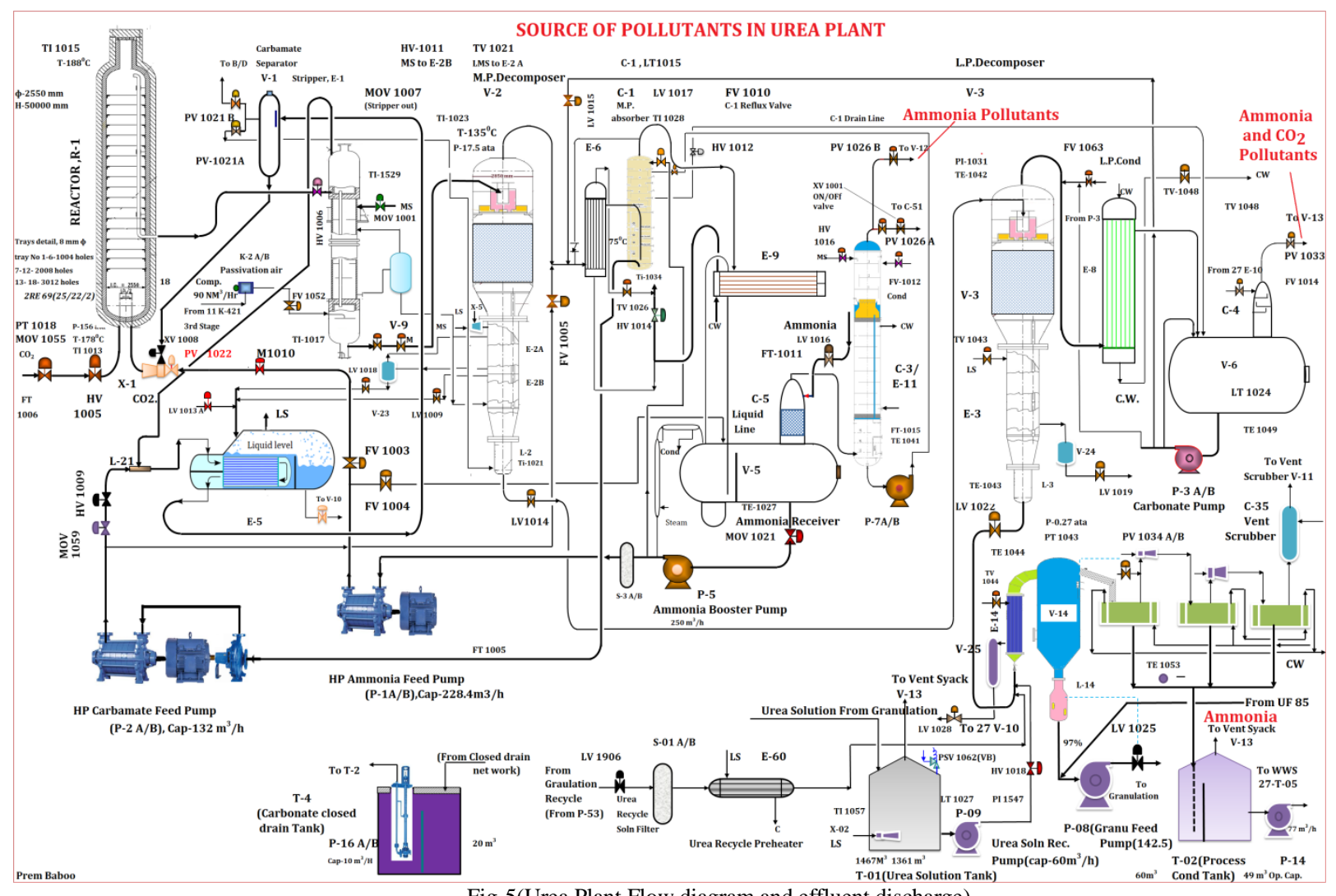

Fig-5(Urea Plant Flow diagram and effluent discharge) 


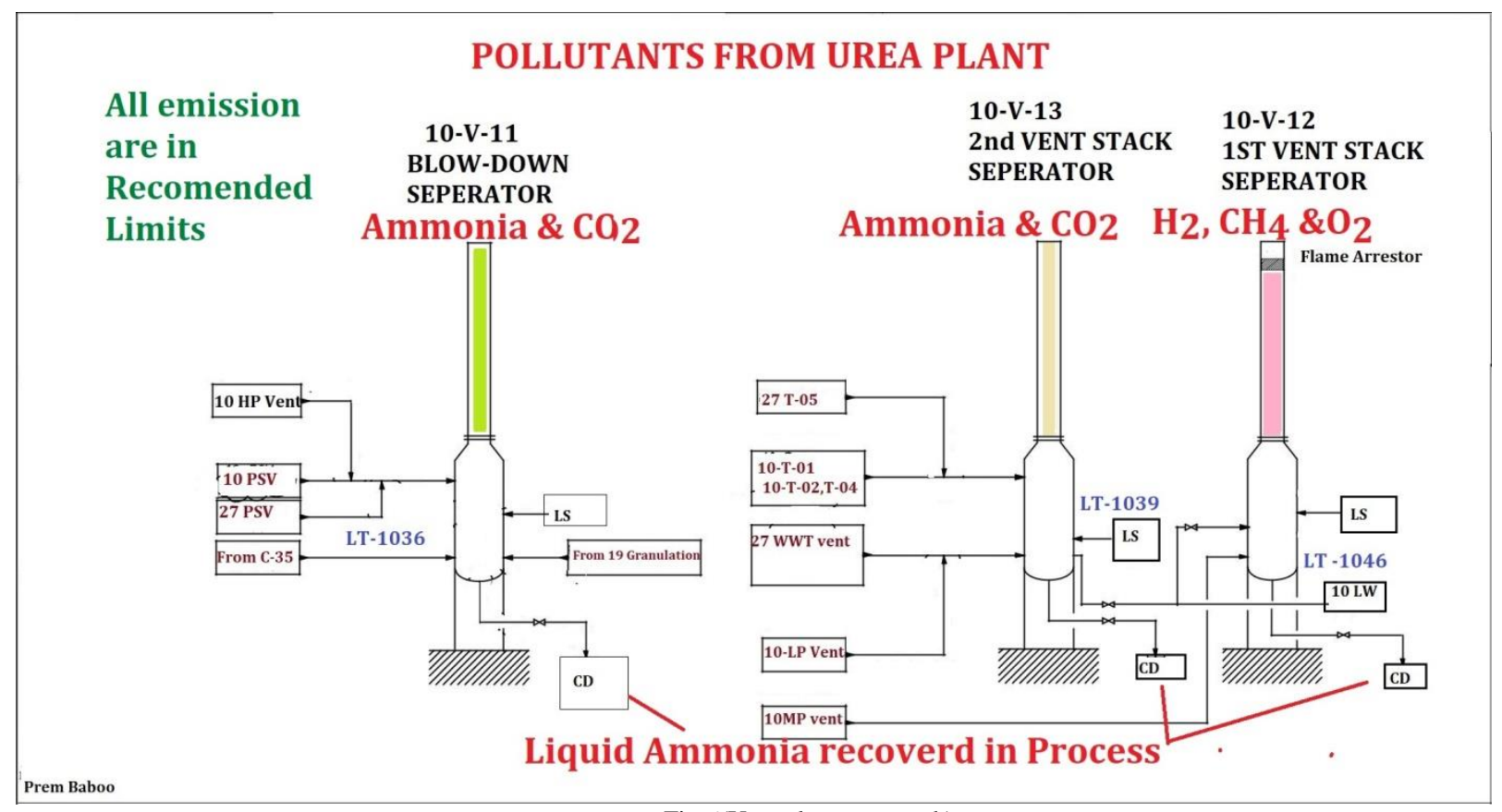

Fig-6(Urea plant vent stack)

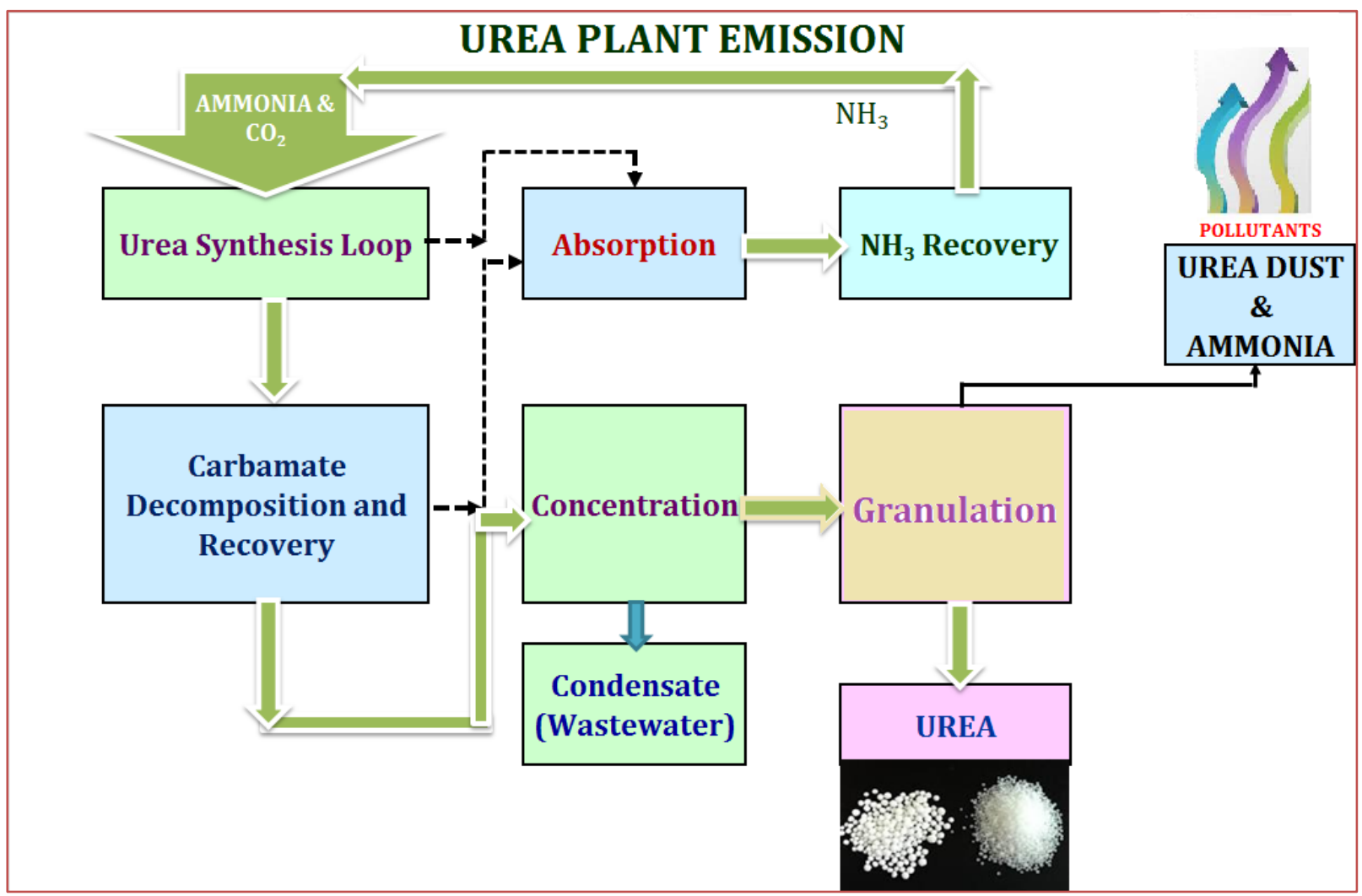

Fig-7(Urea plant pollutants detail) 


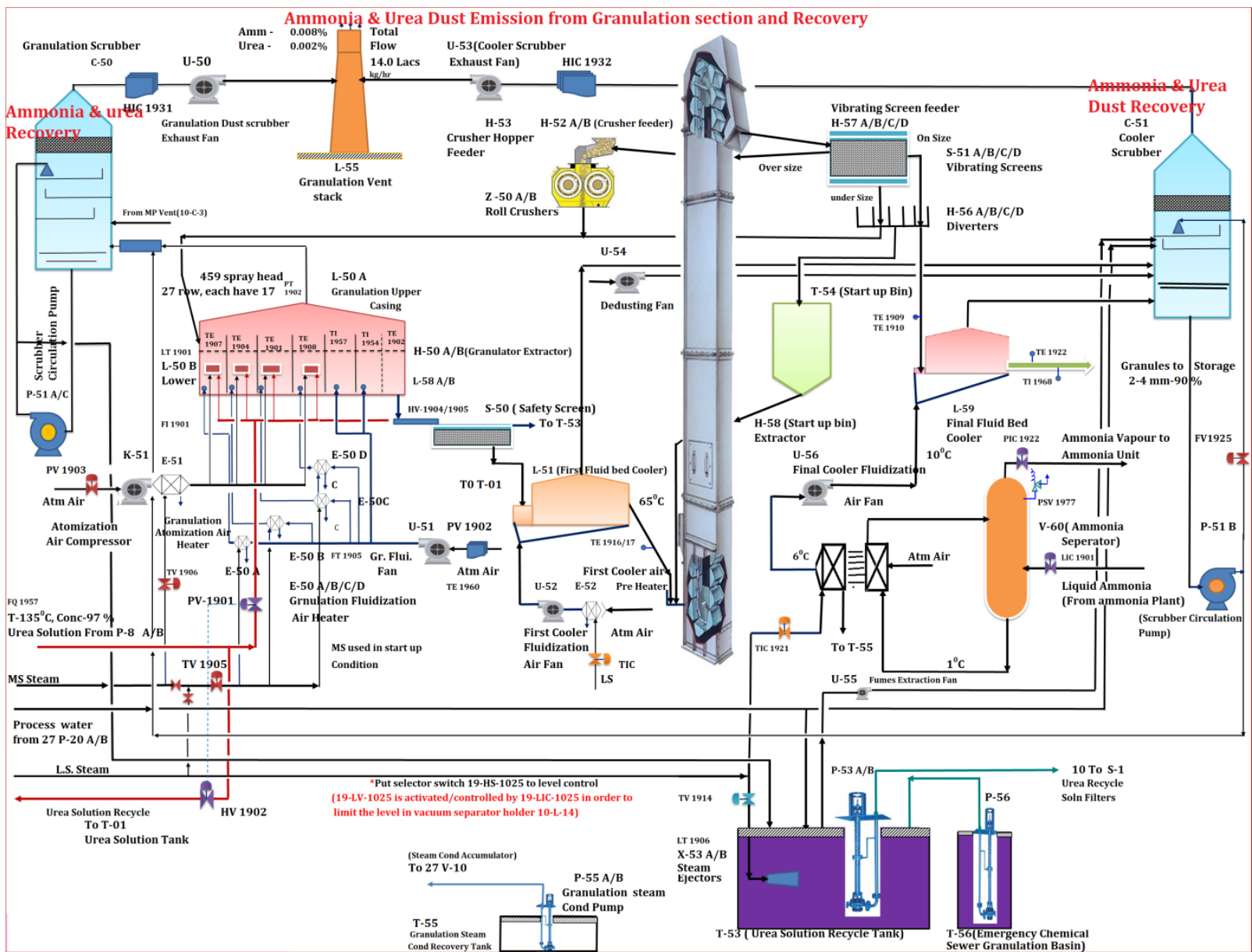

Fig-8(Granulation flow diagram and pollutants)

\section{POLLUTANTS DISCHARGE FROM COLLING TOWER}

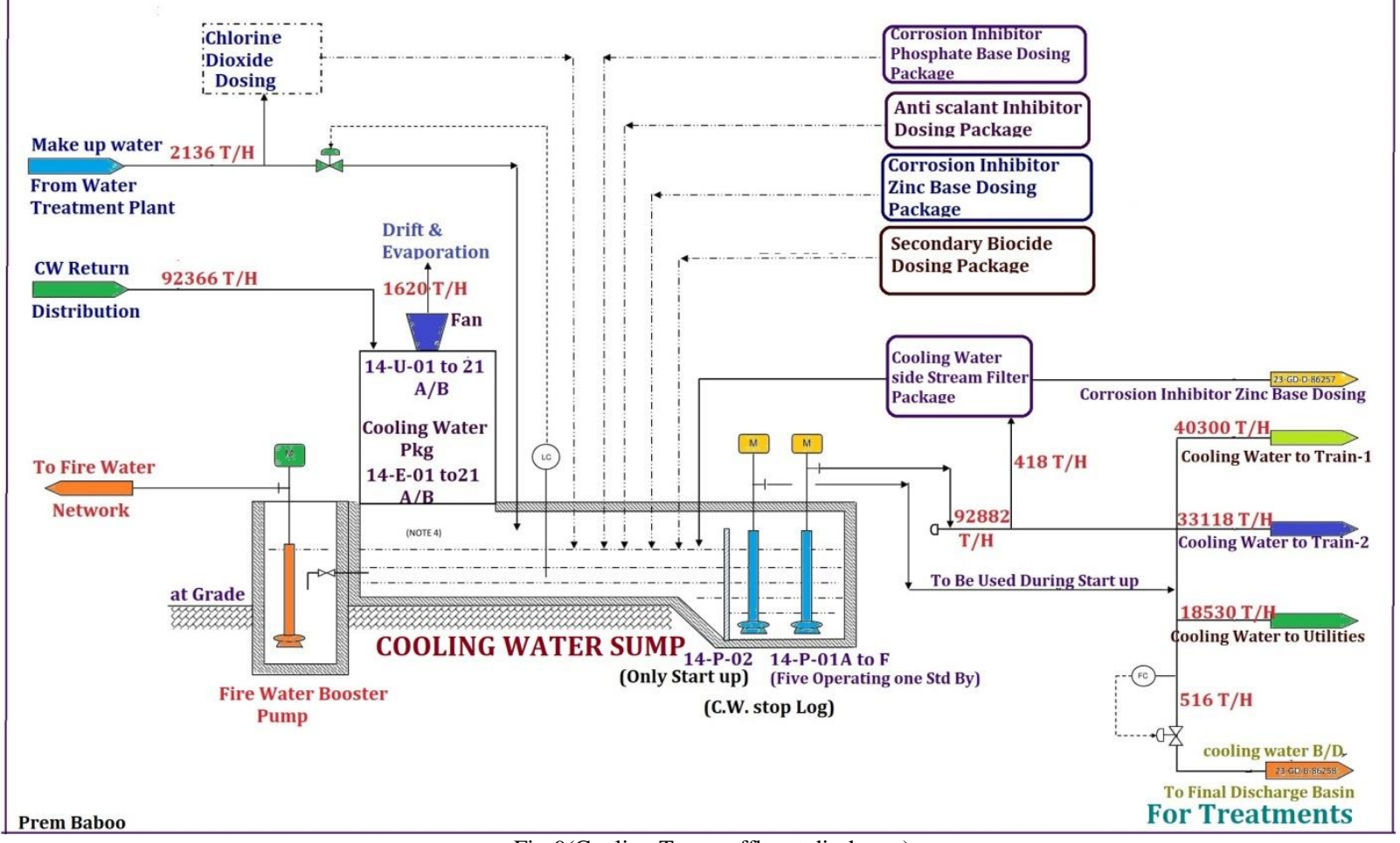

Fig-9(Cooling Tower effluent discharge) 


\section{EFFLUENT TREATMENT SYSTEM}

This section contains a technical description of the Effluent treatment system. This Unit covers the equipment and facilities for collecting and treating waste waters, to allow the final discharge Outside of Fertilizer plant battery limit within the tolerated pollutant concentration limits. This unit includes the following functional sections:

1. Oily rain waters collection and treatment system for oil/water separation.

2. Effluent Treatment System mainly composed by Biological treatment package and Sludge dewatering package.

Biological Treatment Package consist of following equipment.

Anoxic tank mixers, Aeration Tank, with mixer, Anoxic Recycle Pump, Clarifier, Sludge Recycle Pump, Air Blowers, NaOH dosing system, Acetic Acid Dosing system, FeCl3 dosing system, NaOCl Dosing system. The purpose of Sludge Dewatering Package is to obtain the maximum dry content of sludge wastes coming from Bio-treatment and backwash water from Side Stream Filters Package. Biological treatment package provides biological degradation of organics by means of activated sludge. The selected configuration is de-nitrification / nitrification type, to take into account also relevant nitrogen concentrations. The biological reactor is provided a conducive environment for the selective microorganisms to breakdown the pollutants. Biological excess sludge is separated in a final sedimentation basin, and then sent to Sludge Dewatering System. Dried sludge disposal is carry out by truck.

After sludge dewatering, the dewatered sludge is the inform of $18 \%$ dry solids content as minimum. Wastewater may carry a full spectrum of microorganisms, which are too small to seen without the aid of a microscope. The microorganisms can be classified in four groups: bacteria, viruses, protozoa, and helianthus. Out of the four groups, bacteria play the major role in biological treatment. Bacteria degrade the soluble organic matter present in the wastewater and utilize it as food necessary for Growth and reproduction each of the four groups of microorganisms contains some pathogenic species, which can cause diseases. The presence of pathogens in wastewater or treated effluent may adversely affect public health if the wastewater is not treated. The composition of waste commonly discharged varies considerably. In the natural treatment process, it is the naturally occurring bugs, which perform the main task of biodegrading the organic material commonly found in wastewater, in other words these bugs purify the wastewater. Decomposable organic material in wastewater is broken down into less harmful byproducts by the action of the bugs present in the system. Bacteria are the most important of the bugs available for this stabilization process. They use the organic material as food. When the bugs eat the organic material, they obtain the energy required to survive and reproduce. Biological treatment system provides biological degradation of organics by means of activated sludge process. The biological reactor is provided a conducive environment for the selective microorganisms to break down the pollutants. Biological excess sludge is separated in a final sedimentation basin, and then is sent to Sludge Dewatering System. Biological treatment package includes the $\mathrm{pH}$ chemicals dosing systems which is start up based on the characteristics of the waste water and treatment requirements. Biological treatment package is started once it starts receiving effluent from Equalization Basin through bio-treatment feeding pumps. Normally treated effluent from Biological Treatment is sent to Outfall Basin before final discharge; in this basin treated water quality is periodically checked, if it is not in compliance with local environmental regulation (off-spec water quality) treated effluent is pumped again to Equalization Basin by pumps to reduce off spec impact

\section{BUGS + FOOD + OXYGEN = NEW CELLS + ENERGY + STABLE END- PRODUCTS OF BUGS}

When the bugs have consumed the pollutants present in the wastewater, both can be removed by settling. Now the dissolved organic matter has been converted to a form (called sludge), which can be removed by settling. Just like human beings, the bugs need a healthy environment in which to live and grow. This favourable environment includes sufficient residual oxygen, the right number of bugs for the food coming in, suitable $\mathrm{pH}$, adequate temperature, and enough time to digest the food. If these conditions are maintained, and proper sludge wasting and return sludge flow procedures are followed, the bugs is give us a cleaner wastewater. On the contrary, conditions such as too much food for the number of bugs, high flows, lacks of wasting, or too much air may prevent the production of a good clear effluent. This is the basic mechanism by which all biological wastewater treatment systems operate, i.e. biological conversion of organic material to energy, new cells and stable endproducts. The quality of the wastewater is often determined by measuring the Biochemical Oxygen Demand (BOD). The BOD is the amount of oxygen consumed by bacteria in biodegrading the organic matter. In the laboratory, this measurement is usually performed over a 5 days' period at a constant temperature of $20^{\circ} \mathrm{C}$. The measurement is sometimes referred to specifically as $\mathrm{BOD}_{5}$

\section{ACTIVATED SLUDGE PROCESS:}

In the environment, given enough time, treatment of wastes occurs naturally. Activated Sludge treatment is a commonly used biological process, which utilizes the same principles found naturally in the environment. In the Activated Sludge biological treatment process, attempts are made to create an ideal environment to ensure that an adequate number (and type) of bugs are available to feed on the organic matter in the wastewater. This results in a speeding up of the natural process and a more complete conversion of the organic material into stable end-products. In other words, the natural treatment process is, as far as practicable, optimized. The conditions ideally required for the activated sludge process are: 1. sufficient oxygen 2. Suitable temperature, and $\mathrm{pH}$ (measure of acidity) 3. Wastewater contains necessary organic material (food as nutrient) 4 . Correct population of bugs 5 . No toxic compounds. 
These conditions achieve the reduction of organic material and the growth of the bugs into a sludge mass of an activated sludge treatment process. The activated sludge process consists of the following steps:

1. Mixing the activated sludge with the wastewater to be treated.

2. Aeration and agitation of the mixed liquor for the required length of time, and at the appropriate dissolved oxygen level.

3. Separation of the activated sludge from the mixed liquor.

4. Return of the proper amount of activated sludge for mixing with the influent.

5. Disposal of the excess activated sludge.

The first point of interest in the process is the Aeration Tank. Here the wastewater is retained long enough for the bugs to eat the organics in the wastewater. Oxygen and mixing are required for the bugs to come into contact and digest, or metabolize, the organics. The products are new bugs, carbon dioxide, ammonia, and water. Dissolved Oxygen (DO) level between $1.0 \mathrm{mg} / \mathrm{L}$ and $2.0 \mathrm{mg} / \mathrm{L}$ is usually being maintained in the Aeration Tank for this to occur. Ideally, sufficient air is added to the mixed liquor to maintain this level. The process of eating and digestion occurs in two steps. First, the particle sticks to the surface of the bug, this is called "adsorption". After adsorption, "absorption" occurs where the organic material passes through the cell wall of the bug to be digested. The bugs tend to bunch together and form a flock, which occurs, throughout the Aeration Tank. This wastewater-bug mixture is called the "mixed liquor", and the concentration of bugs in the mixed liquor is defined as the "Mixed Liquor Suspended Solids" (MLSS). For a properly operating activated sludge system operating on ordinary wastes, the MLSS concentration is held at the level that gives the best effluent. If the MLSS Concentration or sludge volume is too low, there would not be enough bugs to adequately treat the wastes. If the MLSS concentration is too high, all the bugs may not settle in the Clarifier, which follows the Aeration Tank. The mixed liquor should also have a dark brown colour. The clarifier performs the function of removing the bugs and any floating scum from the wastewater. The settled bugs form what is called activated sludge. The activated sludge is pumped back to the Aeration Tank to maintain the correct level of MLSS. As a guideline the MLSS concentration in the Aeration Tank is between 3000-6000 mg/l. The expression F/M is called Food/Mass ratio and shall normally be between $0.05-0.15$. As an average figure, 0.10 can be used. A figure of 0.10 means the total mass of microorganism in the reactor is (10) times as high as the daily BOD load to the Plant. In other words, the "F" and "M" is defined as:

$\mathrm{F}=$ Food $=$ BOD5 load to the Plant in $[\mathrm{kg} / \mathrm{d}]$

$\mathrm{M}=$ Mass of microorganism in Reactor $=$ MLSS $x$ Volume of Reactor $=\left[\mathrm{kg} / \mathrm{m}^{3}\right] \mathrm{x}\left[\mathrm{m}^{3}\right]=[\mathrm{kg}]$

With the bugs eating the food present in the wastewater there is an increase in their population. When this occurs, some of the activated sludge has to be "wasted" or not returned to the Aeration Tank. This waste sludge (or excess sludge) is usually pumped out of the system. Basics of nitrification and de-nitrification: Nitrification: Nitrification is the two step biological process in which ammonia is first converted to nitrite and then to nitrate.

$$
\begin{gathered}
\mathrm{NH}_{4}+\underset{1.5 \mathrm{O}_{2}}{\rightarrow} \mathrm{NO}_{2-}^{-}+\mathrm{H}_{2} \mathrm{O}+2 \mathrm{H} \\
\mathrm{NO}_{2-}+0.5 \mathrm{O}_{2} \rightarrow \mathrm{NO}_{3}-
\end{gathered}
$$

The overall reaction is as follows

\section{$\mathrm{NH}^{+}+\mathbf{2 O}_{2} \rightarrow \mathrm{NO}_{3}^{-}+2 \mathrm{H}^{+}+\mathrm{H}_{2} \mathrm{O}$}

De-nitrification: - De-nitrification is the biological process by which nitrate is converted to nitrogen and other gaseous end products.

$\mathrm{NO}_{3}-+0.83 \mathrm{CH}_{3} \mathrm{OH} \rightarrow 0.5 \mathrm{~N}_{2}+0.83 \mathrm{CO}_{2}+1.16 \mathrm{H}_{2} \mathrm{O}+\mathrm{OH}-$

The requirements for the de-nitrification process are: a) Nitrogen present in the form of nitrates; b) An organic carbon source, and c) An anaerobic environment.

Besides solids, wastewater may contain small and varying amounts of dissolved gases. The most important of these gases in wastewater treatment is oxygen. Other gases such as carbon dioxide $\left(\mathrm{CO}_{2}\right)$ and hydrogen sulphide $\left(\mathrm{H}_{2} \mathrm{~S}\right)$ are produced as a result of anaerobic decomposition of organic matter. $\mathrm{H}_{2} \mathrm{~S}$ is produced under septic conditions and causes offensive odour. 


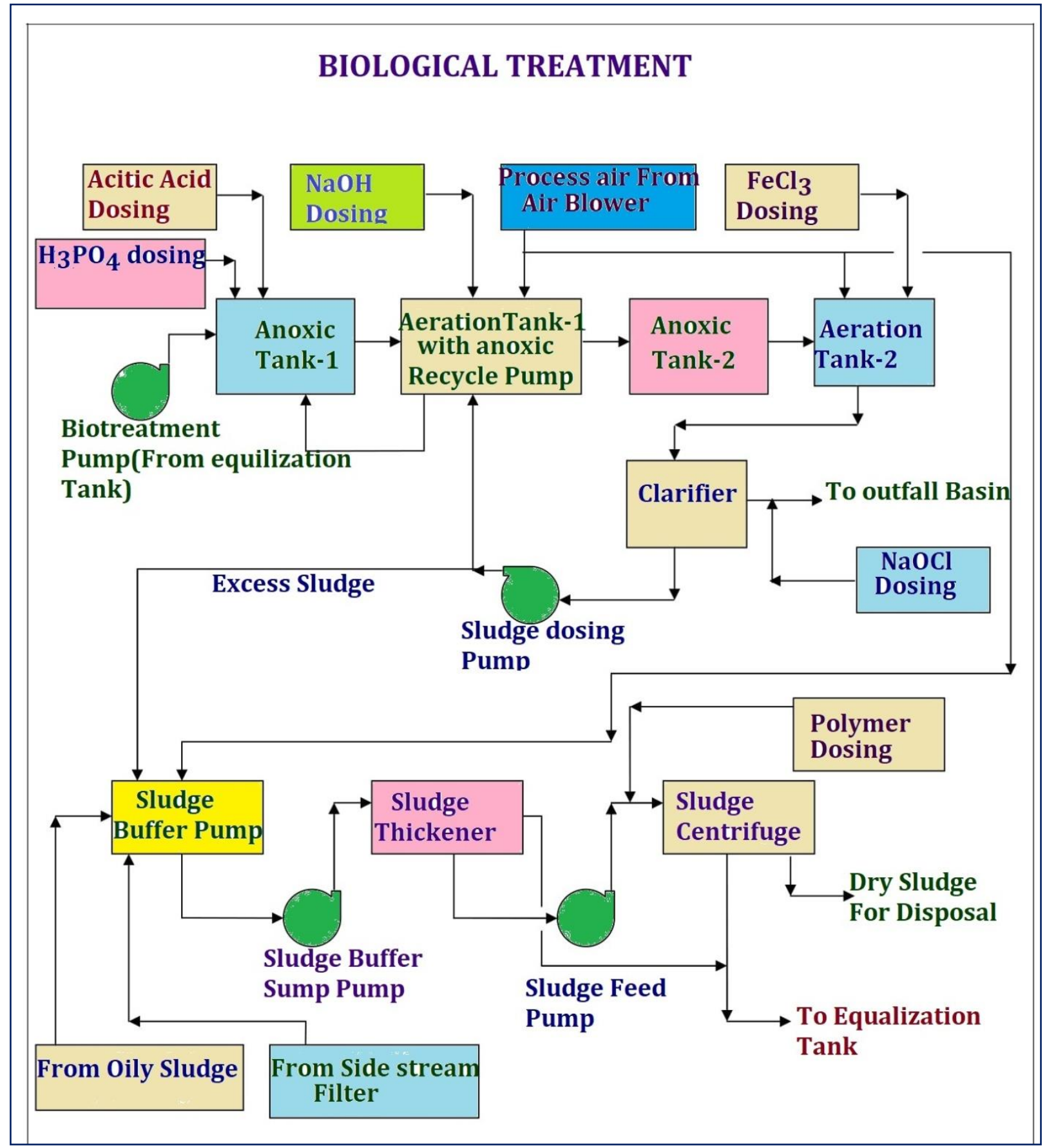

Fig-9(Biological treatment)

\section{EQUALIZATION BASIN}

Equalization Basin protects Biological treatment system from fluctuations in concentrations of organics, nitrogen compounds and flow surges as shown in the figure-10. The overall volume of basin is designed for 24 hrs of hold up considering biological treatment normal capacity. Effluents conveyed to Equalization basin are: CPS Effluent, Laboratory Effluent, Sanitary Effluent, Neutralized Effluents from Packages 12-PK-04/10 and Urea off spec process condensate (for maximum $1 \mathrm{~h}$ before Urea Train 1 and 2 shut down). This last effluent that is normally no flow (a very remote event) has a composition that could be dangerous for Biological System, in case of prolonged duration, then it is mandatory to seek any possible solution to stop the effluent coming from Urea section within 1hour, or to shut-down Urea Train 1 and 2. Submersible mixer system is required in Equalization Basin to avoid anaerobic reactions and to have homogeneous outlet for biological feeding of Biological Treatment Package. As shown in the figure-10 


\section{UTILITIES AREA EQUALIZATION SYSTEM}

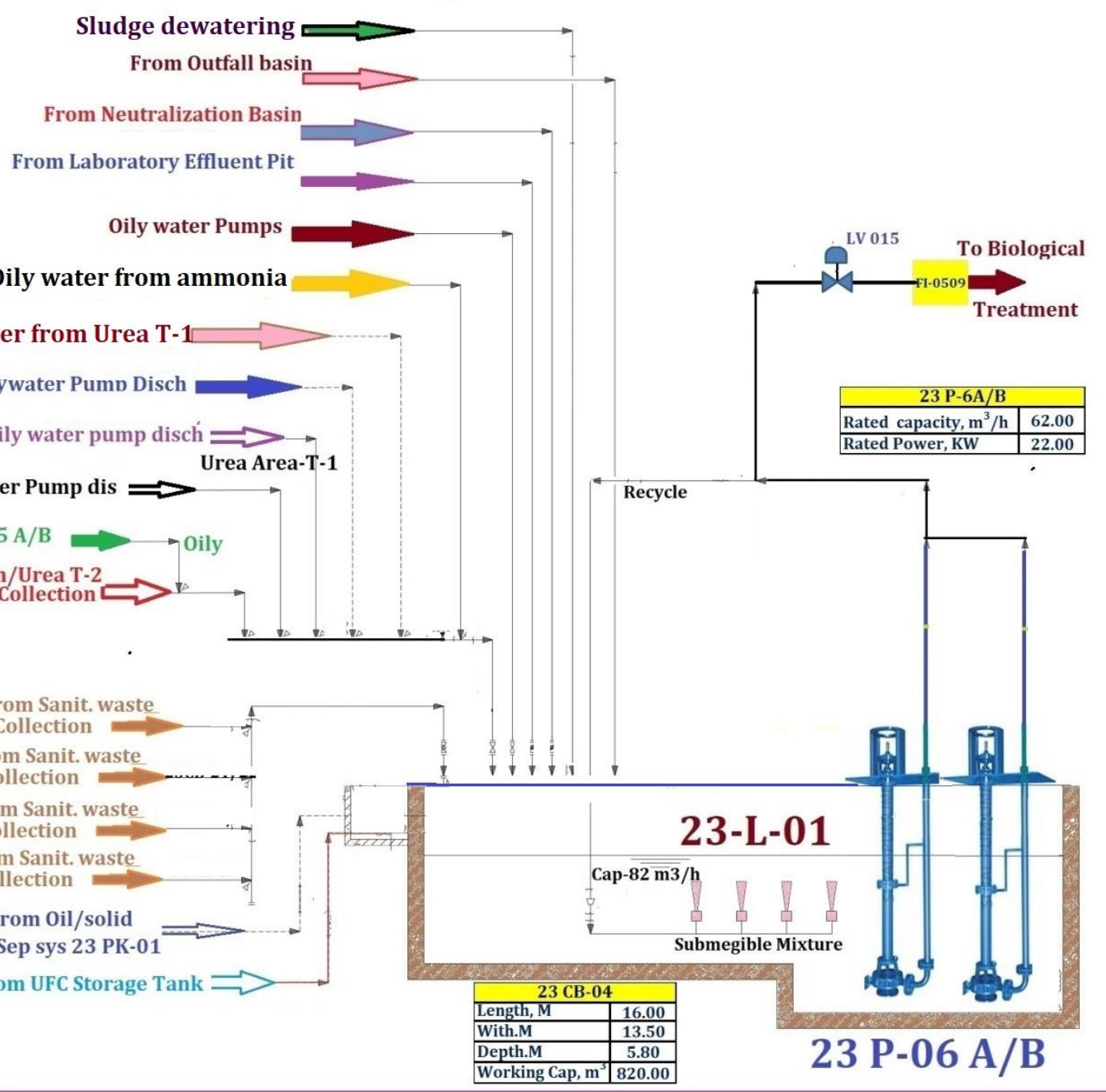

Fig-10(Equalization Basin influent detail)

The Average Daily Flow- $1080 \mathrm{~m}^{3} /$ day

\section{INFLUENT WASTE WATER ANALYSIS}

\begin{tabular}{|c|c|c|c|c|}
\hline Sr.No. & Parameters & Units & August 2019 & January 2020 \\
\hline 1 & COD & $\mathrm{ppm}$ & 30.3 & 29.3 \\
\hline 2 & BOD & $\mathrm{ppm}$ & 13 & 13.4 \\
\hline 3 & TSS & $\mathrm{ppm}$ & 16.8 & 12.7 \\
\hline 4 & TDS & ppm & 4172.6 & 4660.3 \\
\hline 5 & $\mathrm{NH}_{4}^{+}$ & $\mathrm{ppm}$ & 120.2 & 128.8 \\
\hline 6 & $\mathrm{NH}_{4}-\mathrm{N}$ & $\mathrm{ppm}$ & 93.5 & 89.7 \\
\hline 7 & $\mathrm{NO}_{2}^{-}$ & ppm & 0 & 0 \\
\hline 8 & $\mathrm{NO}_{3}^{-}$ & ppm & 3.2 & 1.4 \\
\hline 9 & $\mathrm{NO}_{3}-\mathrm{N}$ & ppm & 0.7 & 0.3 \\
\hline 10 & $\mathrm{Cl}^{-}$ & ppm & 283.3 & 310.1 \\
\hline 11 & $\mathrm{SO}_{4}^{--}$ & ppm & 2225.6 & 2483.1 \\
\hline 12 & $\mathrm{P}$ & ppm & 7.2 & 7.2 \\
\hline 13 & $\mathrm{~Pb}$ & $\mathrm{ppm}$ & 0 & 0 \\
\hline 14 & $\mathrm{Zn}$ & ppm & 0.7 & 0.7 \\
\hline 15 & $\mathrm{HCO}_{3}{ }^{-}$ & ppm & 152.1 & 169.9 \\
\hline 16 & $\mathrm{Ca}^{++}$ & $\mathrm{ppm}$ & 15.5 & 17.2 \\
\hline 17 & $\mathrm{Mg}^{++}$ & $\mathrm{ppm}$ & 6.8 & 7.6 \\
\hline 18 & $\mathrm{Na}^{+}$ & $\mathrm{ppm}$ & 1248.1 & 1394 \\
\hline 19 & $\mathrm{~K}^{+}$ & $\mathrm{ppm}$ & 4.9 & 5.5 \\
\hline 20 & $\mathrm{~F}^{-}$ & $\mathrm{ppm}$ & 0.1 & 0.1 \\
\hline 21 & $\mathrm{Fe}$ & $\mathrm{ppm}$ & 0.1 & 0.1 \\
\hline 22 & Max oil Contents & $\mathrm{ppm}$ & 0.5 & 0 \\
\hline
\end{tabular}




\begin{tabular}{|c|c|c|c|c|}
\hline 23 & MDEA & ppm & 1 & 0 \\
\hline 24 & Urea & ppm & 12.4 & 0 \\
\hline 25 & Urea-N & ppm & 5.8 & 0 \\
\hline 26 & Formaldehyde & ppm & 6.8 & 0 \\
\hline 27 & $\mathrm{CO}_{2}$ & ppm & 1.5 & 1.6 \\
\hline 28 & $\mathrm{SiO} 2$ & $\mathrm{ppm}$ & 10.1 & 11.3 \\
\hline 29 & Boron & $\mathrm{ppm}$ & 5.8 & 6.4 \\
\hline 30 & N Total asN & $\mathrm{ppm}$ & 100 & 90 \\
\hline 31 & $\mathrm{P}$ as $\mathrm{P}$ & ppm & 7 & 7.9 \\
\hline 32 & $\mathrm{p}^{\mathrm{H}}$ & & 6.9 & 6.9 \\
\hline
\end{tabular}

Table-1(Influent waste water analysis)

Sludge water from oil/solid separation Sludge Dewatering

\begin{tabular}{|c|c|c|c|}
\hline Sr. No. & Parameters & Unit & Quantity \\
\hline 1 & Solid loading & Kg/Day & 390.7 \\
\hline 2 & Solid contents & $\%$ & $0.1-3 \%(18 \%$ sludge cake) \\
\hline
\end{tabular}

Table-2(Sludge water flow)

Backwash water from side filters(March-2020)

\begin{tabular}{|c|l|c|c|}
\hline Sr. No. & Parameters & Unit & Quantity \\
\hline 1 & Average Flow & $\mathrm{M}^{3} / \mathrm{Hr}$ & 12.6 \\
\hline 2 & TSS & ppm & 800 \\
\hline 3 & Temperature & C & 34 \\
\hline 4 & $\mathrm{COD}$ & $\mathrm{ppm}$ & 8 \\
\hline 5 & $\mathrm{BOD}$ & $\mathrm{ppm}$ & 2 \\
\hline 6 & $\mathrm{NH}_{4}$ & $\mathrm{ppm}$ & 8 \\
\hline 7 & $\mathrm{NO}_{3}$ & $\mathrm{ppm}$ & 1.2 \\
\hline 8 & $\mathrm{PO}_{4}$ & $\mathrm{ppm}$ & 11 \\
\hline 9 & $\mathrm{HCO}_{3}$ & 100 \\
\hline
\end{tabular}

Table-3(Backwash water analysis and quantity)

In the first scheme the final effluent, comprising washing water from the scrubbing towers in combination with cooling water, is subjected to chemical coagulation-sedimentation using lime. In the second scheme the washing water from the scrubbing towers was chemically treated with recycling of a percentage of the treated effluent. The two treatment schemes are carried out using a continuous flow compact unit. The results obtained revealed that chemical treatment of washing water from the scrubbing towers including recycling treated effluent waste (with a ratio of $1: 2$ ) is recommended. The treatment process proved to be very efficient in removing fluoride, phosphate, silicate and suspended solids. Also, the optimum conditions required for drying the sludge using sludge drying beds were determined. Analysis of the dry sludge indicated that it can be reused with the initial raw material in the plant. A process design of the proposed treatment plant was also included.

\section{AERATION TANK}

Aeration tank of $328 \mathrm{~m}^{3}$ capacity is provided. The tank is constructed of RCC-EPOXY, with the size of $9.5 \mathrm{~m} \mathrm{~L} \mathrm{x} 6.4 \mathrm{~m}$ W x 6.0 $\mathrm{m} \mathrm{H}$. The main biological treatment step is performed in the aeration tanks. The biological treatment of industrial waste is accomplished in the aeration tanks through metabolic activity and adsorption and absorption of organics by biomass/bacteria. The tank is kept aerated through supply of air from air blowers. Here, aeration accomplishes three specific objectives: Supplying the oxygen $\left(\mathrm{O}_{2}\right)$ required sustaining the microorganisms while they consume the organics. - Mixing the return activated sludge from the clarifier with the industrial waste. - Keeping the sludge in suspension by agitation of the mixture. To keep the aerobic environment in the aeration tank, air is supplied through the air blowers. Air requirements are governed by BOD loading, quality of the activated sludge, the solids concentration, and the efficiency of BOD removal.

Aeration blowers are provided with VFD control to maintain the DO in aeration tank. DO analyser provided in the aeration tank controls the blower through VFD to maintain set point DO value. Blower stops at high DO value in aeration tank and starts at low DO value. In the diffused air system, air under low pressure is supplied by blowers through down feed pipes to the bottom of the aeration tank. The air is fed out to the liquid through the fine bubble diffusers. Sodium hydroxide is dosed in the aeration tank to maintain the $\mathrm{pH}$ value of mixed liquor above 6. For this purpose, one $\mathrm{pH}$ Analyse is provided in aeration tank. DO Analyser is provided in Aeration Tank to indicate dissolved oxygen level in the tanks and to control the speed of blower using VFD. One Temperature Transmitter is provided for continuous monitoring of the temperature in aeration tank.

\section{ANOXIC TANK}

Anoxic Tanks of $140 \mathrm{~m}^{3}$ capacity receives biomass from overflow of Aeration Tank This is the treatment step of biological treatment of gentrification for converting $\mathrm{NOx}\left(\mathrm{NO}_{3}, \mathrm{NO}_{2}\right.$, etc.) to nitrogen gas for removal in subsequent aeration tank. The total nitrogen content after this treatment is reduced below $10 \mathrm{ppm}$. Anoxic tank is provided with the submersible mixers to keep the biomass in suspension. Provision to dose Acetic acid is made as external carbon source. The material of construction of tank is RCC-EPOXY with size of $4 \mathrm{~mL}$ X $6.4 \mathrm{~mW}$ X $6 \mathrm{mH}$, provided with ORP Analyser for continuous monitoring of oxygen level to maintain anoxic condition in the tank. Tank is also provided with $\mathrm{pH}$ analyser for continuous monitoring of $\mathrm{pH}$ in the tank. 


\section{CLARIFIER}

One Clarifier constructed of RCC-EPOXY material, with the size of $12.8 \mathrm{~m}$ Dia x $3.5 \mathrm{~m}$ H is provided. After the nitrification gentrification and aeration process the mixed liquor flows to the clarifier where the activated biomass is separated from the liquid during a period of quiescent settlement. The settled biomass called sludge is pumped back to the Anoxic Tank to maintain the biological population. Precipitated phosphorus is also removed by settling. Continuous return of activated sludge to the Aeration tank is provided to maintain the required MLSS in the aeration tank. In the process, excess sludge built up in the clarifier is taken out regularly from the system into Sludge Buffer sump. The settled sludge concentration in the clarifier is 0.6$0.7 \%$. Clarifier is equipped with rake mechanism which operates continuously. Clarified water flows by gravity to the outfall basin. One flow transmitter is provided at the outlet of clarifier to monitor the flow to the outfall basin. One online chlorine analyser is also provided at the outlet of clarifier to monitor the free chlorine in clarified water and also its control the stroke of $\mathrm{NaOCl}$ dosing pump.

\section{PLC OPERATION}

The pumps are operated in Hand or Auto Mode by switching the respective Hand-Off Auto selector switch provided on HMI. Hand Mode Operation. In hand operation mode, each pump can be started and stopped manually from the HMI. Auto Mode Operation in auto operation mode, duty pump starts and stops automatically based on following condition.

1. Duty pump - starts at high level in sludge buffer sump.

2. Duty pump - stops at low level.

\section{SLUDGE THICKENER}

One thickener is constructed of RCC-EPOXY material, with the size of $5.3 \mathrm{~m}$ Dia x $3.5 \mathrm{~m} \mathrm{H}$. After the collection of biological sludge, backwash water from side stream filter and oily sludge in sludge buffer sump the sludge buffer sump pump is transfer the sludge to the thickener where the solids are separated from the liquid during a period of quiescent settlement and get thickened. The thickened sludge is pumped to the centrifuge by sludge feed pump and overflow of thickener i.e. supernatant is continuously go to equalization tank basin. Thickener is equipped with rake mechanism which operates continuously. The expected TSS concentration of thickened sludge is $3 \%$.

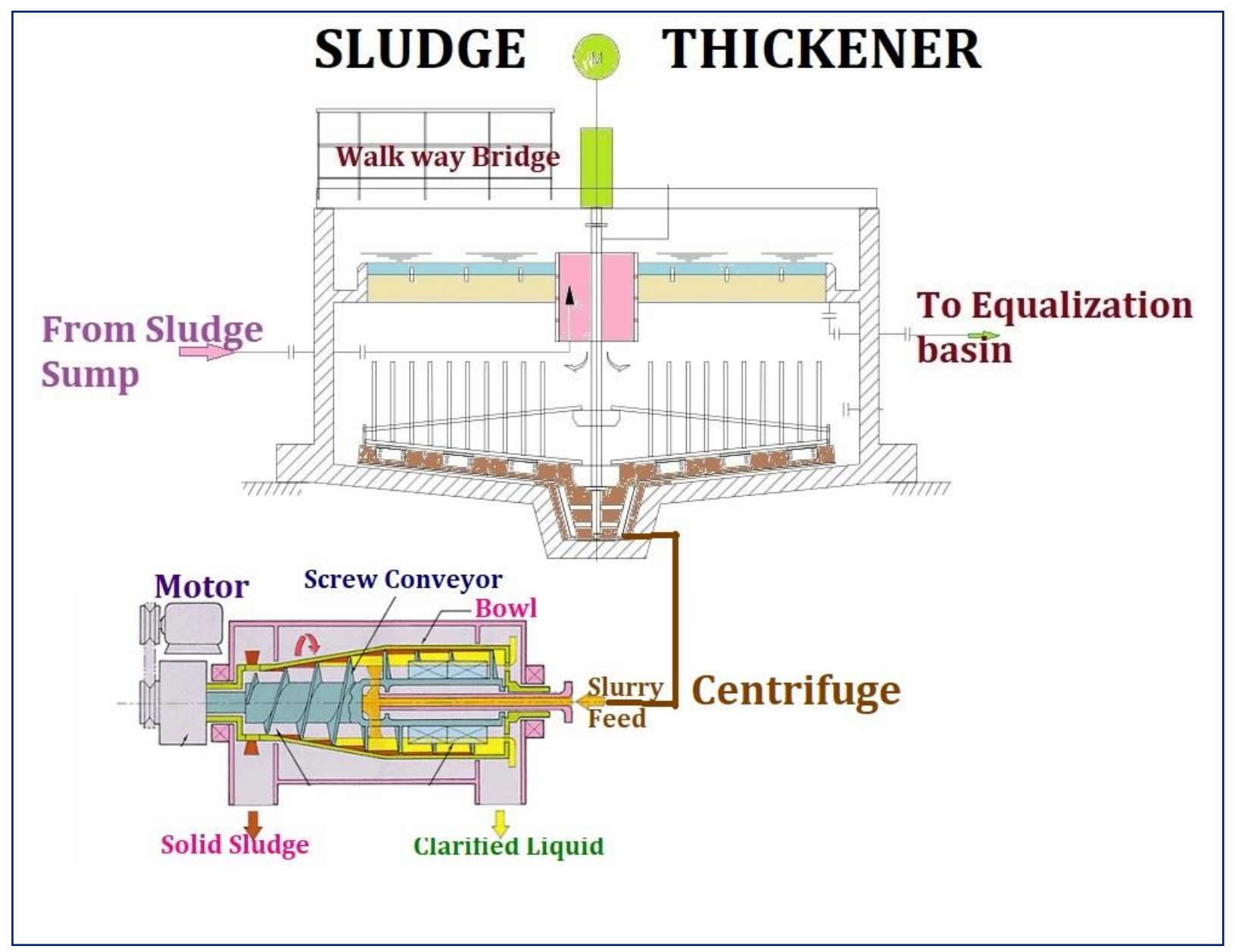

Fig-11(Sludge thickener \& Centrifuge) 


\section{SLUDGE CENTRIFUGE}

Sludge Centrifuge receives the sludge from the Sludge Feed Pump at a $1.75 \mathrm{~m}^{3} / \mathrm{hr}$ feed rate. The provided capacity of Sludge centrifuge is $3 \mathrm{~m}^{3} / \mathrm{hr}$. The sludge centrifuge is schedule for five days in week and 8 hours' operation in a day. Liquid polymer in diluted form $(0.2 \%)$ is dosed in the feed tube connected to the Centrifuge for effective solid separation in the Centrifuge from the Polymer System. The Centrifuge is of the solid bowl type with an internal scroll. The solid bowl has a cylindrical section for the efficient clarification of the liquid and a conical section for dewatering of the solids. The feed enters the Centrifuge through the feed (inlet tube) and passes through the distributor and accelerator. Due to the centrifugal forces (generated by the rotation at high speed), the solid particles are settled onto the internal bowl wall. The scroll rotates in the same direction of the bowl, but at a slower speed, thus moving the solids towards the conical end of the bowl for discharge. The cake leaves the bowl through the solids discharge opening. Separation takes place throughout the entire length of the cylindrical part of the bowl, and the clarified liquid (centrate) leaves the bowl by flowing over adjustable plate dams (weir). The bowl is driven by main drive and power is transferred to the bowl by V-belts. The scroll (screw conveyor) is driven by a back drive system and a reduction gearbox. Centrifuge motors are provided with VFDs to maintain the required differential speed. The Centrifuge is provided with vibration switch, temperature transmitters for the main bearing and bowl speed measurement. To maintain consistent cake dryness, the Centrifuge is operated on the constant torque principle which varies the differential speed between the bowl and the scroll to keep the scrolling torque constant during operation when the solids loading varies due to fluctuations in feed sludge concentration. The expected sludge cake concentration is $\min .18 \%$. The Centrifuge is flushed with service water during every stoppage. The service water flushing valve opens automatically during the shutdown cycle for flushing of the unit.

\section{POLYMER DOSING TANK}

Polymer Dosing System is designed for the dilution of liquid polymer to $0.2 \%$ concentration. The liquid polymer of 50\% concentration is pumped from the polymer drum by Polymer unloading pump and injected in the Polymer Dosing Tank. Capacity of tank is 700 lit. And material of construction is SS-316. Service water regulated manually through a variable-area flow meter, is added in the tank for the dilution of polymer to the desired concentration. The tank is provided with an agitator for proper mixing. The service water feed line is provided with a solenoid valve to operate automatically when the unit is operated and flow indicator to adjust the water flow manually. The diluted polymer is injected to Sludge centrifuge feed inlet by Polymer Dosing Pumps. The Polymer Dilution System is a stand-alone unit having its own control panel being interfaced with the centrifuge's operation

\section{ACETIC ACID DOSING TANK}

One Acetic Acid Dosing Tank of $4.5 \mathrm{~m} 3$ capacity is provided for min. 7 days' storage. The tank receives the liquid acetic acid chemical from top with the help of electrically operated acetic acid Barrel Pump. The provided capacity of Acetic Acid Barrel Pump is $10 \mathrm{~m} 3 / \mathrm{hr} @ 1 \mathrm{barg}$. The material of dosing tank is GRP. The size of tank is $1.9 \mathrm{~m}$ Dia x $1.95 \mathrm{~m} \mathrm{H}$. The Acetic acid is pumped (dosing flow rate - $31 \mathrm{lph}$ ) by Acetic Acid Dosing Pumps to Anoxic tank/Anoxic tank The tank is equipped with Level Transmitter.

\section{$\mathrm{NaOH}$ DOSING TANK}

One $\mathrm{NaOH}$ Dosing Tank of $3 \mathrm{~m} 3$ capacity is provided for min. 7 days' storage. The tank receives the liquid $\mathrm{NaOH}$ from top with the help of electrically operated $\mathrm{NaOH}$ Unloading Pump. The provided capacity of $\mathrm{NaOH}$ unloading pump is $6 \mathrm{~m} 3 / \mathrm{hr} @$ 1 barg. The material of dosing tank is GRP. The size of tank is $1.6 \mathrm{~m}$ Dia $\times 1.85 \mathrm{~m} \mathrm{H}$. The $\mathrm{NaOH}$ is pumped by NaOH Dosing Pumps to Aeration tank-1. The tank is equipped with Level Transmitter. One electric heater is provided in the NaOH Dosing Tank to heat the caustic solution to avoid freezing. Heater has inbuilt thermostat to on / off the heater and will maintain the minimum temperature of caustic $20^{\circ} \mathrm{C}$.

\section{SODIUM HYPOCHLORITE DOSING TANK}

One $\mathrm{NaOCl}$ Dosing Tank of $1.5 \mathrm{~m} 3$ capacity is provided for min. 7 days' storage. The tank receives the liquid $\mathrm{NaOCl}$ from top with the help of electrically operated NaOCl Barrel Pump. The provide capacity of NaOCl Barrel Pump is $3 \mathrm{~m} 3 / \mathrm{hr} @ 1$ barg. The material of dosing tank is GRP. The size of tank is $1.5 \mathrm{~m}$ Dia $x 1.5 \mathrm{~m} \mathrm{H}$. The $\mathrm{NaOH}$ is pumped by $\mathrm{NaOCl}$ Dosing Pumps to Clarifier outlet. Sodium hypochlorite used for disinfection of treated wastewater before discharging into outfall basin. The tank is equipped with Level Transmitter.

\section{$\mathrm{FeCl}_{3}$ DOSING TANK}

One $\mathrm{FeCl}_{3}$ Dosing Tank of 300 lit capacities is provided for min. 7 days' storage. The tank receives the liquid $\mathrm{FeCl}_{3}$ from top with the help of electrically operated $\mathrm{FeCl}_{3}$ Barrel Pump. The provided capacity of $\mathrm{FeCl}_{3}$ Barrel Pump is $1 \mathrm{~m} 3 / \mathrm{hr} @ 1$ barg. The material of dosing tank is GRP. The size of tank is $0.8 \mathrm{~m} \mathrm{Dia} \times 1.2 \mathrm{~m} \mathrm{H}$. The $\mathrm{FeCl}_{3}$ is pumped by $\mathrm{FeCl}_{3}$ Dosing Pumps to Aeration tank to precipitate the Phosphorous. The tank is equipped with Level Transmitter.

\section{MINUTE SETTLEMENT TEST}

The purpose of this crude test is to check the build-up of bacteria in the system. The quantity of sludge in the plant should be checked after 20 days from each routine start up and daily on trouble shooting conditions. This test is done at each alternate day. Take one of the Measuring Cylinders provided with the plant and fill it to the 1-liter mark with Mixed Liquor form the Aeration Zone - Allow all solids to settle for 30 minutes. - Read off the volume of solids, that has settled in the 30-minute period. If the solids are less than $30 \%$ ( reference value) of the volume, no action is required but, if a greater quantity is recorded, the quantity of Activated Sludge is high and to be wasted. Plot the sludge settling data as shown in Example Curve 
as figure number-12. A typical plant that is operating properly should develop a similar curve. In each plant, a particular curve is occur when all phases of the plant are operating well; i.e., clear effluent, good settling in the clarifier and proper colour. This curve, reflecting good operation of the plant, becomes the curve that the operator strives to maintain.

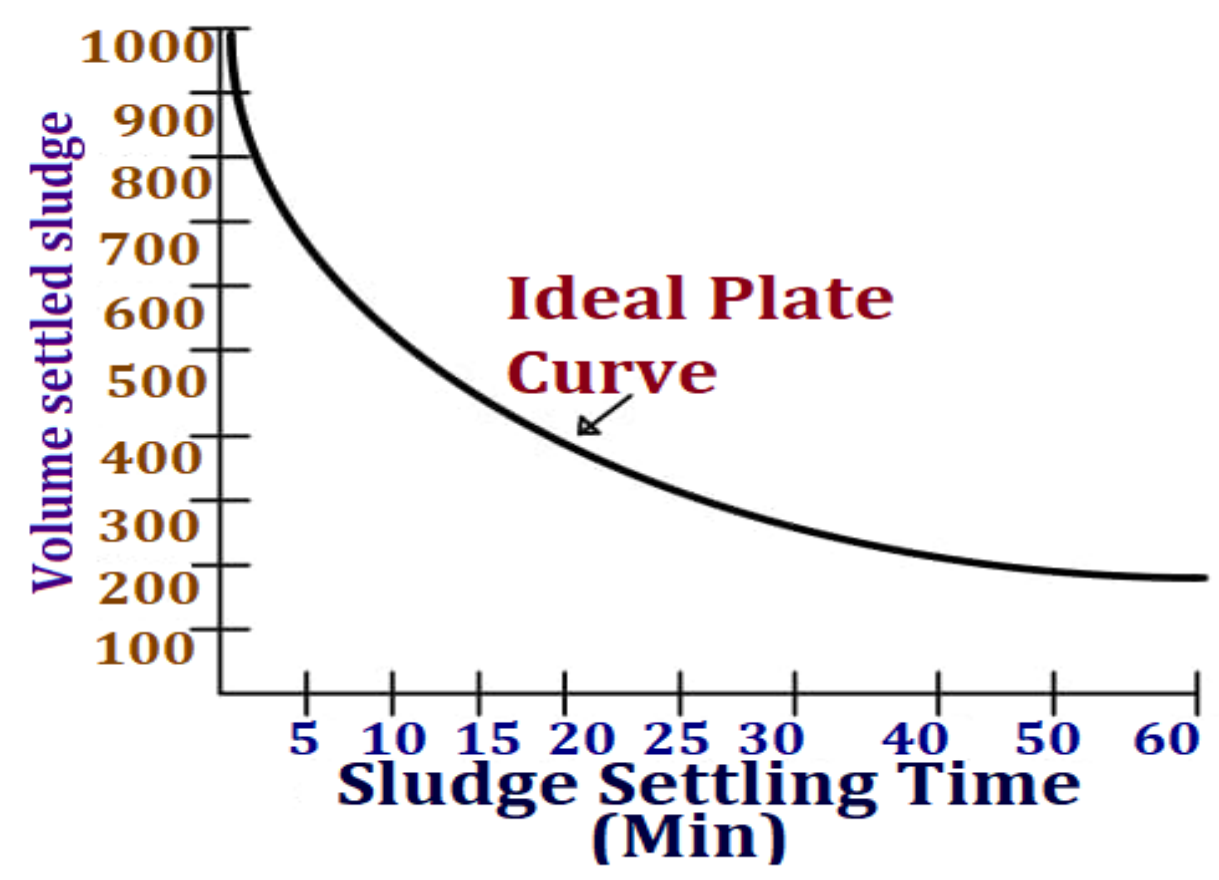

Fig-12(Time Vs Sludge settling)

SANITARY WASTE WATER

The system is collected sanitary effluents from buildings into dedicated sumps located in proximity of each building. The collected effluent flow rate is based on an average human consumption of about $1 \mathrm{~m}^{3} / \mathrm{h}$ considering a total of 120 persons for each work shift and 200 litres of sanitary water per person in a day (24 m3/day).

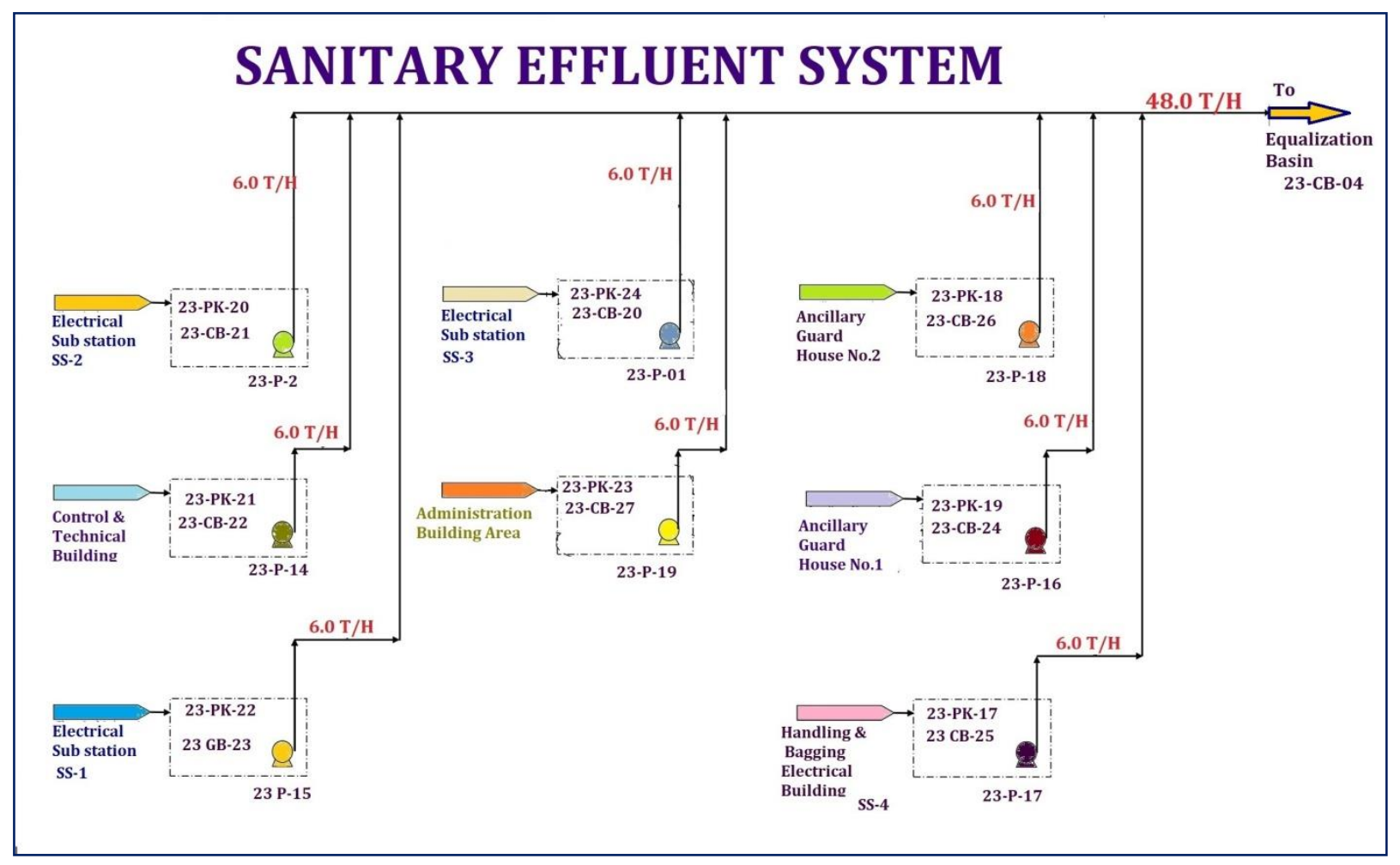

Fig-13(Detail of sanitary waste flow quantity) 


\section{OIL SEPARATION UNIT}

Oil Separation Unit is configured for a total design inlet flow-rate of $7.5 \mathrm{~m}^{3} / \mathrm{h}$ with following inlet maximum concentrations:

1. TSS: $300 \mathrm{ppm}$

2. $\mathrm{pH}: 6-9$

3. Oily water and grease: $1200 \mathrm{ppm}$

4. Oil specific gravity: $0.9 \mathrm{~kg} / \mathrm{dm} 3$

De-oiled effluent is sent to Equalization Basin or Observation Basin and, according to Nigerian \& International Effluent Limitation Guidelines, shall have the maximum Content of:

1. TSS: $\leq 30 \mathrm{ppm}$;

2. Oil and grease: $\leq 10 \mathrm{ppm}$.

Overall inlet stream flow-rate: $7.5 \mathrm{~m}^{3} / \mathrm{h} \sim$ (continuous normal flow-rate, after rainfall event) Effluents from the unit consists of Water overflows from oily water sumps, Oil from Oil/Solids Separation system, Sludge from Biological treatment and water drainage from Biological Treatment. Overflow water from Oily water sumps are routed to civil open channel. Water from Observation basin is send to Final Discharge Basin for final disposal. Oil from Oil skimmer is disposed by vacuum truck. Water drainage from Biological treatment is negligible \& intermittent and is routed to open drains. Sanitary waste water is sent to Biological treatment before disposal. Disposal of Sludge from Biological treatment is On Hold and to be confirmed based on Package Data Utilities Requirements.

\section{OILY RAIN WATER COLLECTION AND SEPARATION SYSTEM}

Oily rain waters from ammonia plant, urea plant and utilities area are composed by: storm water, fire fighting water, equipment spillages from paved area and wash water with no chemical contamination. The main streams influencing the design are storm water and fire fighting water due to their large amount. The first flush of $5 \mathrm{~mm}$ of storm water or firewater (with potential oil contamination) falling on the paved areas of ammonia, urea and utility plants stocked into Oily Water Sumps, while the remaining storm water or firewater (second flush, considered clean) is sent by gravity, by means of an overflow, into an open channel for final discharge to LEKKI Lagoon. Stocked oily waters are pumped. CPS (Corrugated Plates Separator) Oil Separation Unit. at controlled flow-rate of $7.5 \mathrm{~m}^{3} / \mathrm{h}$. One Oily Water Sump per time manually emptied after storm or fire event end manually by operator. PS is a separator based on gravity in which corrugated plates (or equivalent) aid the coalescence of oil drops and so the oil-water separation. CPS has three outlet streams:

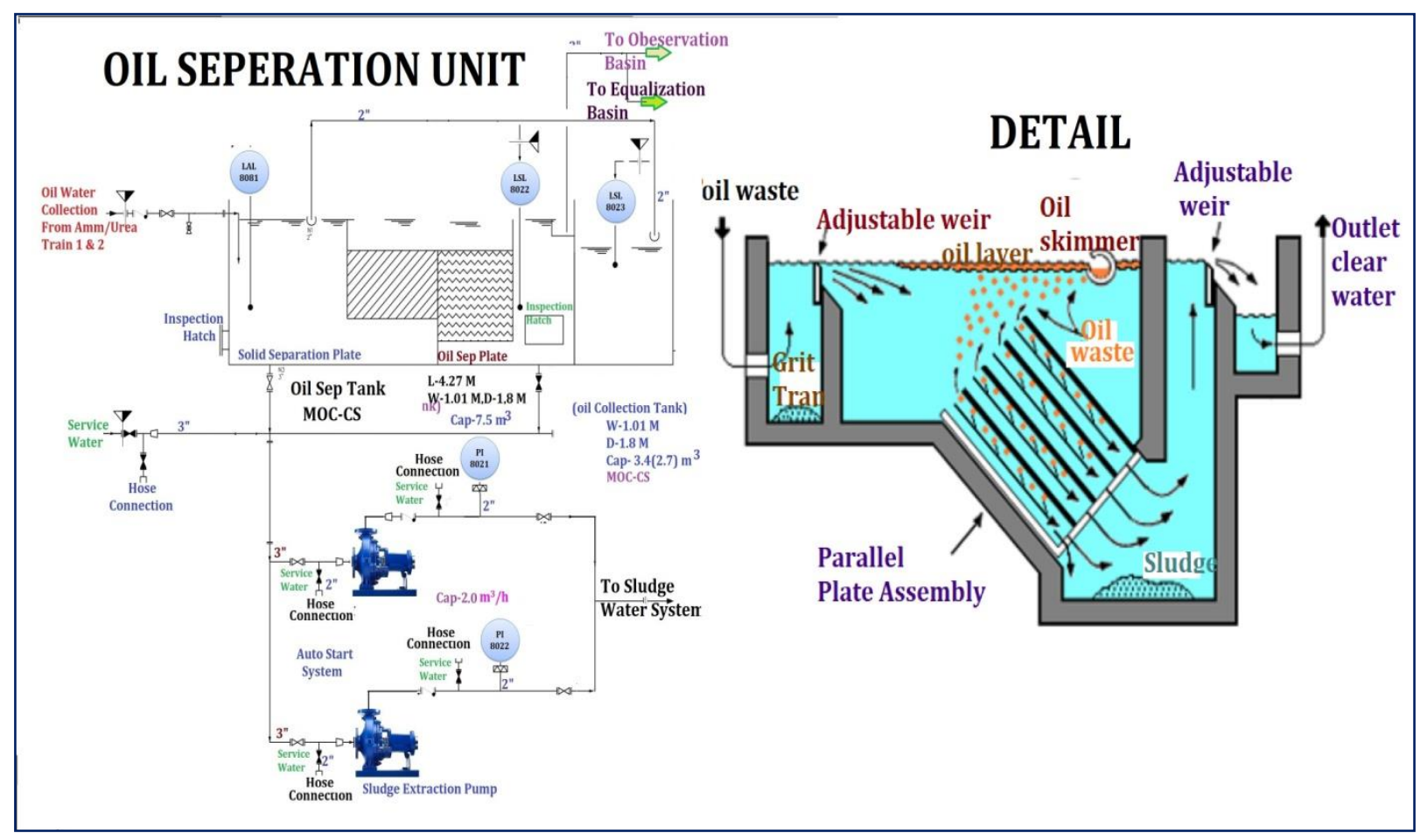

Fig-14(Oil separation mechanism)

Separated oil, water and sludge. Oil from CPS is stocked in an adjacent Oil Vessel. The sludge is sent to Sludge Dewatering System. De-oiled water coming out from CPS is sent to the Observation Basin with a maximum flow rate of $7.5 \mathrm{~m}^{3} / \mathrm{h}$, except for water considered contaminated with ammonia or urea that goes to Equalization Basin at controlled flow-rate of $7.5 \mathrm{~m} / \mathrm{h}$. From the Observation Basin, the water is Pumped to the Final Discharge Basin and then is sent to final disposal at Battery limit. 


\section{EFFLUENT TREATMENT OF DM WATER FACILITIES}

A dedicated Neutralization System is provided for effluents of Desalination Package. This system, Effluent Treatment System. Effluents are collected in a neutralization basin that is equipped with ejector tore circulate the inlet water. The overall basin capacity is sufficient to contain two complete regeneration of cationic and anionic resins of desalination unit, so water is closer to $\mathrm{pH}$ neutrality. In the neutralization basin $\mathrm{pH}$ is adjusted around 7 by means of addition of sulphuric acid or caustic soda. The quantity of acid and soda added are regulated by the average value of two $\mathrm{pH}$ analysers and a feedback system depending of out coming water $\mathrm{pH}$. The water recirculation helps mixing of chemical and water; when the water reaches the desired $\mathrm{pH}$ range, it can be directly discharged to Equalization Basin and then fed to Biological Treatment. A dedicated Neutralization System provided for effluents of Demineralization Package.

\section{SLUDGE DEWATERING SYSTEM}

In an effort to reduce the sludge disposal cost, the sludge dewatering process into the system is applied. After sludge dewatering, the dewatered sludge shall be in form of $18 \%$ dry solids content. Sludge Dewatering System receives the following streams: CPS sludge, Biological Sludge and Side Stream Filters backwash water. Dewatering Supernatant shall be recirculated upstream the biological treatment.

\section{OBSERVATION BASIN}

Observation Basin collects all treated discharges from the plant unit. Water is pumped. Out of the basin by $23-\mathrm{P}-30 \mathrm{~A} / \mathrm{B}$ pumps to the final discharge basin. Floating Oil Skimmer is installed in the basin to remove accidental oil entered in the basin. Oil from Oil Skimmer is sent to an oil sump included in the basin. Oil sump shall be emptied by vacuum truck.

\section{FINAL DICHARGE BASIN}

Final Discharge Basin collects the blow down water and treated water. Water isPumped out of the basin by $23-\mathrm{P}-40 \mathrm{~A} / \mathrm{B} / \mathrm{C} / \mathrm{D}$ pumps to the B.L. Raw Water Treatment Plant.

\section{UREA WASTE WATER TREATMENTS}

Provision of separate high pressure Urea Hydrolyser section for treatment of $158 \mathrm{M}^{3} / \mathrm{hr}$. process water generated during Urea production process from both train $1 \&$ train-2. Finally treated water is of such a good quality that it is used as boiler feed water. As shown in the figure-15. The main source of process water is the urea synthesis reaction:

$$
2 \mathrm{NH}_{3}+\mathrm{CO}_{2} \rightarrow \mathrm{CO}\left(\mathrm{NH}_{2}\right)_{2}+\mathrm{H}_{2} \mathrm{O}
$$

Where $300 \mathrm{~kg}$ of water are formed per ton of urea. urea plant of 2X3850 T/D generates theoretically about 2304 Ton water/day ( 96T/hr). This water contains $6.2 \% \mathrm{NH}_{3}, 1.2 \% \mathrm{CO}_{2}$ and $0.56 \%$ urea (by weight). In the analyzed plant, two main waste water sources are evidenced:

(a) oily wastewaters from pumps and compressors seals, floor waters;

(b) wastewaters from ammonia recovery;

The air emissions consist mainly in ammonia, and they are located in three points:

a) The exhausters of the urea scrubber vent

b) Gas exhaust from the L.P Vent;

c) Gas exhaust from the distillation tower reflux accumulator vent.

All emissions are below the designed value, but they are lower than the maximal allowed concentration, established by legal regulations. The condensed vapors from the vacuum systems containing $\mathrm{NH}_{3}$, Urea, $\mathrm{CO}_{2}$ and water are collected in the process condensate tank, In this tank, the solution of close drain (CD) collected tank are also fed by means of pump $27-\mathrm{P}-16 \mathrm{~A} / \mathrm{B}$. From $10-\mathrm{T}-02$ it is pumped to waste water tank $27-\mathrm{T}-05$. From this tank it is pumped by $27-\mathrm{P}-25 \mathrm{~A} / \mathrm{B}$ to the distillation tower C-2. Before entering the distillation tower the process condensate is pre-heated in the exchanger 27-E-16 where the heating medium is purified condensate flowing out distillation tower bottom. Since the solution is contaminated by urea, after a first stripping in the upper part of the distillation tower it is umpped by $27-\mathrm{P}-15 \mathrm{~A} / \mathrm{B}$ into the hydrolyser R-2 where the urea is decomposed by means of super-heated steam (HS) at 38 Ata and $381^{\circ} \mathrm{C}$. The process flow diagram is shown in the figure -15 . Before entering the hydrolyser, the solution is pre-heated in the exchangers with the solution coming from the hydrolyser. The vapours leaving the hydrolyser jointly with the vapors coming from the distillation tower Overhead condenser wherefrom the carbonate solution lows to the reflux accumulator.

The purified waste water from the bottom of distillation tower is cooled in E-18 A/B and purified wastewater cooler before going out the urea plant B/L. During start-up and transitory, the waste water is recycled to $27-\mathrm{T}-05$ until it reaches the composition specified. As already pointed out in the process description, the liquefied effluent treatment section consists mainly of a stripping column to purify the waste water and a hydrolyser to decompose the small percentage of urea into $\mathrm{NH}_{3}$ and $\mathrm{CO}_{2}$, which are eventually stripped in the lower section of the same distillation tower column. The vapors leaving the distillation tower column top are mixed with those coming from the hydrolyser are condensed in overhead condenser. The heat is removed by cooling water. 
The hydrolysis reaction of urea is the opposite of that occurring in the reactor, Viz.

$$
\mathrm{NH}_{2} \text {. CO. } \mathrm{NH}_{2}+\mathrm{H}_{2} \mathrm{O} \quad 2 \mathrm{NH}_{3}+\mathrm{CO}_{2}-\Delta
$$

Therefore, urea decomposition is favored by;

- High temperature,

- Low pressure,

- $\mathrm{NH}_{3}$ and $\mathrm{CO}_{2}$ deficiency and

Also sufficiently long residence time has proved to be an important character. In order to remove $\mathrm{NH}_{3}$ and $\mathrm{CO}_{2}$ as far as possible before feeding hydrolyser, the waste water coming from the vacuum condensers is first stripped in the column. Moreover, a series of baffles in the hydrolyser provide a plug flow effect, thus avoiding back mixing. Also the continuous removal of the hydrolysis reaction products is provided and this encourages the decomposition of urea. By eliminating $\mathrm{NH}_{3}$ and $\mathrm{CO}_{2}$ to the maximum extent, it is possible to maintain the pressure in the system at a relatively low value, while attaining rather high temperatures. For this proposal a $220^{\circ} \mathrm{C}$ temperature has been envisaged together with a 45 minute residence time. However we are maintaining $\sim 234^{\circ} \mathrm{C}$ to attain required composition. Vents from all the process vessels and safety valves are connected to separators from where liquid effluent is sent back of Urea Hydrolyser section for further treatment and gases are vented to atmosphere from $60 \mathrm{M}$ high vent. The ammonia concentration at working place is less than $20 \mathrm{ppm}$.

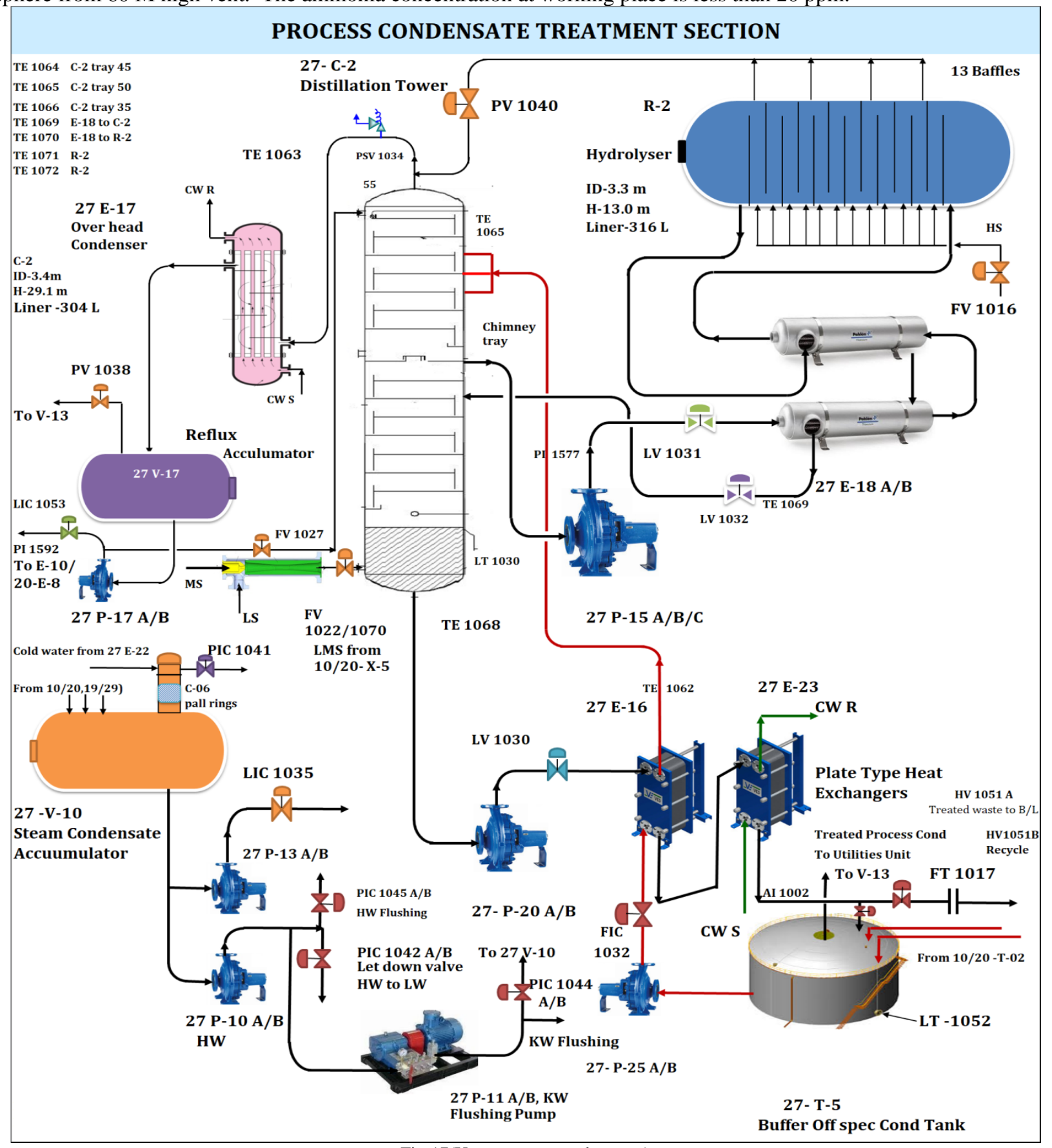

Fig-17(Urea waste control system) 


\section{AMMONIA RECOVERY}

The Ammonia Recovery section from common unit for both ammonia train sand its purpose is recovered the ammonia in the purge gas from the loops of both ammonia trains and from various low pressure off-gases, and to deliver it as $99 \%$ liquid ammonia. The section includes the following main items with associated heat exchangers, pumps, and KO drum:

1. The Purge Gas Absorber.

2. Off Gas Absorber.

3. Distillation Column

In the purge gas absorber, ammonia is removed from the high pressure purge gas by absorption in water. The purified purge gas is routed to the burners of the auxiliary boilers. In the off gas absorber, ammonia is removed from the let-down gas from inert vent gas by absorption in water. The purified off gas together with the purified purge gas is routed to the burners of the auxiliary boilers. The rich ammonia solution from the absorbers is regenerated in the distillation column. Lean solution is taken from the bottom of the column and $99 \%$ liquid ammonia can be drawn off from the overhead separator. At the outlet the flue gas temperature is reduced to approx. $189^{\circ} \mathrm{C}$. A Flue gas blower takes the flue gas to the Flue gas stack. Due to the low temperature at the outlet of the second ammonia chiller the partial pressure of ammonia in the gas phase is low; therefore, only a minor amount of ammonia will be removed together with the purge gas. The purge gas is, however, cooled further in the purge gas chiller to condense the ammonia, which is separated in the purge gas separator The liquid ammonia is then returned to the ammonia separator. To recover the ammonia content of the purged inert vent gas stream, the ammonia is condensed in inert vent gas chiller and separated in inert vent gas separator. The remaining ammonia content is recovered in the ammonia recovery unit.

\section{CHEMICAL \& CATALYST}

Chemical solutions for the operation of the main effluent treatment packages are as follows:

1. Sulphuric Acid for Neutralization Basin injected from Unit-12, 12-PK-04/10.

2. Caustic Soda for Neutralization Basin injected from Unit-12, 12-PK-04/10.

3. Sodium hypochlorite for Biological Treatment System (23-PK-04).

4. Urea-formaldehyde solution (called UFC-85) is added at granulation feed pumps (10-P-08 A/B) suction as granulation anti-caking agent. This additive has the following characteristics:Fomeldehyde- $60 \%$, Urea- $25 \%$ rest is water.

\section{FLARES AND BLOWDOWN SYSTEM}

This unit is designed to dispose the Blow Down gases safely from the Front End and Back End Section of both the Ammonia Plants (Train $1 \& 2$ ). All the vent stack height and pollutant given in the table number-4

This system consists of 2 separate flaring systems here below described:

1. Ammonia Back End Flare.

2. Ammonia Front End Flare

\section{AMMONIA PLANT BACK- END FLARE SYSTEM}

This system has been designed for the collection and combustion of process, ammonia rich gas. It is composed by an Elevated Flare System, which is supplied as a package (25-PK-01) and installed inside the fertilizer Complex. Back-end flare is common to both Ammonia Plants and is designed for Ammonia.

1. Compressor Blocked Outlet relief from one ammonia plant (Train 1 or 2).

2. This Scenario is not foreseen for both Ammonia Plants (Train $1 \& 2$ ) simultaneously.

3. Max allowable gas tip exit velocity shall be $0.5 \mathrm{Mach}$

Flare total height (TIP included) - $75 \mathrm{~m}$ Stack diameter - 36" Stack design pressure $-3.5 \mathrm{~kg} / \mathrm{cm}^{2}(\mathrm{~g})$

\begin{tabular}{|c|c|c|c|c|c|}
\hline \multicolumn{6}{|c|}{ Different Vent Stacks } \\
\hline Sr. No. & Vent Stacks & $\begin{array}{l}\text { Height } \\
\text { Meters }\end{array}$ & Diameter & \begin{tabular}{|c|} 
Design Pressure, \\
$\mathrm{Kg} / \mathrm{cm}^{2} \mathrm{~g}$
\end{tabular} & Fluid \\
\hline 1 & Ammonia Flare stack( Train 1 \& 2) & 75 & $36 ", 62 "$ & \begin{tabular}{|l|}
3.5 \\
\end{tabular} & Natural Gas, $\mathrm{NH}_{3}, \mathrm{CO}_{2}$ \\
\hline 2 & Ammonia storage Flare Stack & 15 & $10 "$ & 3.5 & Ammonia \\
\hline 3 & Urea Blow down stack| & 60 & $\begin{array}{c}48 " \text { Vent, } 4.5 \text { meter } \\
\text { on Bottom ID }\end{array}$ & 0.3 & $\mathrm{CO}_{2}, \mathrm{NH}_{3}, \mathrm{H}_{2} \mathrm{O}$ Vapour \\
\hline 4 & $\mathbf{1}^{\text {st }}$ Vent Stack with Flame arrester & 60 & $\begin{array}{c}\text { 8" Vent,1.5 meter on } \\
\text { Bottom ID }\end{array}$ & 0.3 & $\begin{array}{c}\mathrm{Ar}, \mathrm{H}_{2} \\
, \mathrm{~N}_{2}, \mathrm{NH}_{3}, \mathrm{CH}_{4}, \mathrm{O}_{2}, \mathrm{~N}_{2}, \\
\text { Steam } \\
\end{array}$ \\
\hline 5 & $2^{\text {nd }}$ Vent Stack & 60 & $\begin{array}{l}20 " \text { Vent, } 1.5 \text { meter } \\
\text { on Bottom ID }\end{array}$ & 0.3 & $\mathrm{CO}_{2}, \mathrm{NH}_{3}, \mathrm{H}_{2} \mathrm{O}$ Vapour \\
\hline 6 & Granulator Vent Stack & 44 & $4.8 \mathrm{mtrs}$ & 0.3 & Urea , $\mathrm{NH}_{3}$ \\
\hline 7 & Boiler 1, 2 \& 3 Vent Stack & 35 & & & $\mathrm{CO}_{2}$, Nox,SOx \\
\hline
\end{tabular}

Table-4(different vent stack height and fluid) 


\section{AMMONIA STORAGE SYSTEM}

Ammonia Storage System mainly covers the requirements of Liquid Ammonia Storage, transfer of liquid ammonia and ammonia vapour from/to Ammonia-Urea Plants, Storage Refrigeration and Flaring of Ammonia Vapour's during emergency conditions.

The unit includes the following functional sections:

1. Ammonia Storage Tank (30-T-01).

2. Transfer of Liquid Ammonia from Ammonia plants to Urea plants by Ammonia process transfer pump (30-P-01)

3. Transfer of Ammonia Vapour to Ammonia Plants by Ammonia Vapour Displacement Blower (30-U-01).

4. Ammonia Stand-by Refrigeration Package (30-PK-02).

5. Ammonia Storage Flare (30-PK-01).

6. Ammonia Drainage Pit. (30-CB-01)

AMMONIA STORAGE FLARE

Ammonia Storage Flare (30-PK-01) is dedicated to Ammonia storage section and it is sized considering the worst scenario of the system, i.e. Ammonia BOG Compressor Blocked Outlet condition with a Blow-down Gas flow-rate of 1132 Nm3/h (860 $\mathrm{kg} / \mathrm{h})$. Stream Data and Characteristics as follows:

\begin{tabular}{|l|l|}
\hline Type of relief sizing event & General \\
\hline Flared Gas & Ammonia $\left(\mathrm{NH}_{3}\right)$ \\
\hline Molecular Weight & 17.03 \\
\hline Blow-down Gas flow-rate & $1132 \mathrm{Nm} 3 / \mathrm{h}(860 \mathrm{~kg} / \mathrm{h})$ \\
\hline Components mole & \\
\hline$\% \mathrm{NH}_{3}$ & 100 \\
\hline Operating Temperature & $-33^{\circ} \mathrm{C}$ \\
\hline Design Temperature & $-45 / 70^{\circ} \mathrm{C}$ \\
\hline Total allowed press. drop (Stack, Seal \& Tip) & $200 \mathrm{~mm} \mathrm{H} 2 \mathrm{O}($ Note 1,2$)$ \\
\hline LHV of Blow-down Gas & \\
\hline & $3375 \mathrm{kcal} / \mathrm{Nm}^{3}$ \\
\hline
\end{tabular}

The maximum consumption of Fuel Gas necessary to assist the complete combustion of the ammonia gas, discharged at the said flow rate, shall be minimized. The estimated consumption of fuel gas is $130 \mathrm{~kg} / \mathrm{h}$, during the emergency flaring of the design stream. The fuel / assist gas consumption is indicative only and the same verified and confirmed.

\section{EFFLUENT TREATMENTS FROM AMMONIA AREA}

The drains from Ammonia refrigeration package are routed to ammonia blow down pit and from there water is added from utility stations to reduce the concentration of ammonia in the effluent to traces before disposing to sewer. If at all any liquid level is observed in Ammonia Flare Drain provision are available for disposing to sewer. In Urea Plants, liquid effluent treatment system fully integrated in the process is provided to recover ammonia by distillation. In addition, a hydrolyser is provided in order to eliminate completely the urea present in the process condensate. Ammonia and Inerts effluents are continuously discharged from 10-C-03(medium pressure vent) and 10-C-35(Vacuum section Vent) as shown in the urea flow diagram figure-5 \&8. Vent from $10-\mathrm{C}-03$ is collected to granulator scrubber or diverted to continuous Vent stack $10-\mathrm{V}-12\left(1^{\text {st }}\right.$ vent stack separator) in case of granulation unavailability. Vent from 10-C-35 is collected to 10-V-11(Blow down Separator). As shown in the figure-6. The main sources of Effluent from the Unit are Cooling water Blow down, drainage from Chemical dosing system and Drainage from Side stream filtration Unit as shown in the figure-9. Cooling Water blow down is routed to Water Treatment Plant Unit through Battery Limit or is sent to Final Discharge Basin for final disposal. Drainages from Hypochlorite dosing system, Corrosion inhibitor dosing system and Anti-scalant dosing package are sent to open funnels system. The drainage from Side stream filtration unit is sent to Sludge Dewatering system.

\section{UFC STORAGE SYSTEM}

UFC storage system covers the necessary equipment and facilities to store liquid Urea Formaldehyde $85 \%$ Concentrated (UFC) and to transfer it by dedicated dosing pump system to the Urea Granulation Trains 1 and 2. This unit includes the following functional sections:

1. UFC Storage Tank (31-T-01) which is filled by trucks by means of UFC Unloading Pump (31-P-01).

2. UFC Transferring System (31-P-02A for train 1,31-P-02B for train 2 plus 31-P-02C as common spare pump).

Effluent generated in this Unit is due to Water drainage from UFC storage tank. This is a very rare operation and is sent to Equalization Basin (23-CB-04) or Observation Basin (23-CB-11) for Disposal.

The diagram of urea total recycle process is shown in the figure-5.

\section{DEDUSTING SYSTEM}

The purpose of the de-dusting circuit is to collect dust at the locations where dust generation is likely to occur. Those locations are:

1. At the top of the bucket elevators $19-\mathrm{H}-51 \mathrm{~A} / \mathrm{B}$

2. Roll crushers $19-\mathrm{Z}-50 \mathrm{~A} / \mathrm{B} / \mathrm{C} / \mathrm{D}$ 
3. Vibrating Screens $19-\mathrm{S}-51 \mathrm{~A} / \mathrm{B} / \mathrm{C} / \mathrm{D}$

4. Discharge point on first conveyor belt

5. At the top of Start-Up Bin 19-T-54

The de-dusting is catered for by de-dusting fan. The flow rate can be adjusted manually at each suction point. The dust laden air is sent to coolers scrubber for further treatment. Scrubbing off gas with process condensate prior to venting inerts in atmosphere, the granulation section consists of granulation scrubber for scrubbing ammonia and urea the cooler scrubber recovers ammonia and urea from first bed cooler and final bed coolers. The diagram of Granulation process is shown in the figure- 8

TREATED WASTE WATER QUALITY (February-2020)

\begin{tabular}{|c|l|c|}
\hline \multicolumn{1}{|c|}{ Parameter } & \multicolumn{1}{|c|}{ Value } \\
\hline 1 & Biological Oxygen Demand(BOD) & $30 \mathrm{ppm}$ \\
\hline 2 & Chemical Oxygen Demand(COD) & $125 \mathrm{ppm}$ \\
\hline 3 & Total Suspended Solids(TSS) & $30 \mathrm{ppm}$ \\
\hline 4 & Total Nitrogen & $10 \mathrm{ppm}$ \\
\hline 5 & $\mathrm{NO}_{3}$ & $20 \mathrm{ppm}$ \\
\hline 6 & Total Phosphorus & $1.7 \mathrm{ppm}$ \\
\hline 7 & Residual Chlorine & $0.5-1.0 \mathrm{ppm}$ \\
\hline 8 & $\mathrm{pH}$ & $6.0-8.5$ \\
\hline
\end{tabular}

Table-6(Treated waste water quality)

CONCLUSION

In general improvement in the process technology of ammonia \& urea has concentrated on reducing production cost and minimizing the environmental impact. A coordinated approach comprising of an effective utilization of available asset, development of Biological treatments regular laboratory analysis assisted by advanced continuous treatment. This exercise has proven reliability and sustainability of the system. The DFL exercise is valuable for new development at lower cost. The main objective is to reduce urea content in treated water to less than $1 \mathrm{ppm}$ so that it can be used as any service as requirements. Considerable quantities of ammonia and urea arc discharged continuously along with the vacuum condensate. In modern urea plants, the quantities of ammonia and urea discharged has been reduced appreciably be process modification. Some urea and ammonia are occasionally discharged which originate from spillage, leakage of glands, flanges, joints, etc., floor washings and also from draining during shutdown and start-up of plants, in modern plants these discharges are collected and recycled. A stream of cooling water purge containing conditioning chemicals and biocides is discharged from the cooling tower continuously. The method is low cost and at the same time enhances the fertilizer value of sewage sludge. It therefore has a large potential of competing with more established methods of sanitization.

\section{LEGENDS.}

HSE-Health, safety \& Environments, HTAS-Haldor Topsoe Assessments, MTPD-Metric Ton per day, UFC-Urea Formaldehyde Concentrate, TSS-Total suspended Solid, CPS -Corrugated Plates Separator, MDEA-Methyl Di Ethanol Amine, HP-high pressure, VFD-variable frequency drive. ORP-Oxidation Reduction Potential.

\section{REFERENCES}

[1] Effluent Treatment and Bio hydrolyser for Ammonia and Urea Plant waste streams by Prem Baboo ,Technical paper June 2015 on www.ureaknowhow.com.

[2] Management of waste water from fertilizer Industry by Sohair I. Abou, and Enas Mouhamed Aboutateb, Egypt, water science and Technology Dec 1995.

[3] Industrial wastewater treatment for fertilizer industry- A case study by Vinay M. Bhandari, Laxmi Gayatri Sorokhaibam and Vivek V. Ranade Chemical Engineering \& Process Development Division CSIR- National Chemical Laboratory Pune-411 008. India.

[4] Environment Management and advance waste treatment system in Nitrogenous Fertilizers Plant by Prem Baboo on Research Gate, Feb 2016. 